\title{
TGF- $\beta$ Family Signaling in Neural and Neuronal Differentiation, Development, and Function
}

\author{
Emily A. Meyers and John A. Kessler \\ Department of Neurology, Feinberg School of Medicine, Northwestern University, Chicago, \\ Illinois 60611 \\ Correspondence: emilymeyers2015@u.northwestern.edu
}

Signaling by the transforming growth factor $\beta$ (TGF- $\beta$ ) family is necessary for proper neural development and function throughout life. Sequential waves of activation, inhibition, and reactivation of TGF- $\beta$ family members regulate numerous elements of the nervous system from the earliest stages of embryogenesis through adulthood. This review discusses the expression, regulation, and function of TGF- $\beta$ family members in the central nervous system at various developmental stages, beginning with induction and patterning of the nervous system to their importance in the adult as modulators of inflammatory response and involvement in degenerative diseases.

$T_{\text {him }}^{\text {he }}$ he transforming growth factor $\beta$ (TGF- $\beta$ ) family plays a central role in multiple aspects of nervous system development and function. During embryogenesis, TGF- $\beta$ family members regulate the initial formation of the nervous system, dorsalization and establishment of rostrocaudal boundaries, patterning of the central nervous system (CNS), stem-cell lineage commitment to neurons and glia, cell migration and axon guidance, synaptogenesis, and cell survival (see Table 1 ). During adulthood, TGF- $\beta$ family members modulate inflammatory responses, influence quiescence in neural stem cells of the hippocampus, and have a role in neurodegenerative disease. This review will cover the expression, regulation and function of TGF- $\beta$ family members in the CNS from early development to adult life.

\section{NEURAL INDUCTION}

Formation of the neural plate, the first step in the genesis of the nervous system, is triggered during gastrulation by signals produced by an organizer region on the dorsal blastophore lip (Fig. 1) (Spemann and Mangold 1924). These signals act primarily by inhibiting signaling by TGF- $\beta$ family members including bone morphogenetic proteins (BMPs), nodal, and activin (Hemmati-Brivanlou and Melton 1992, 1994). Noggin, follistatin, and chordin, the first neural inducers that were identified (Hemmati-Brivanlou et al. 1994; Sasai et al. 1994, 1995), act by suppressing BMP signaling (Piccolo et al. 1996; Zimmerman et al. 1996; Fainsod et al. 1997). Additional BMP antagonists secreted from the organizer include Cerberus, Gremlin,

Editors: Rik Derynck and Kohei Miyazono

Additional Perspectives on The Biology of the TGF- $\beta$ Family available at www.cshperspectives.org

Copyright (C) 2017 Cold Spring Harbor Laboratory Press; all rights reserved; doi: 10.1101/cshperspect.a022244

Cite this article as Cold Spring Harb Perspect Biol 2017;9:a022244 
E.A. Meyers and J.A. Kessler

Table 1. Summary of some known actions of transforming growth factor $\beta$ (TGF- $\beta$ ) family members in the nervous system

\begin{tabular}{|c|c|c|}
\hline $\begin{array}{l}\text { TGF- } \beta \text { family } \\
\text { member }\end{array}$ & Effects of antagonism & Synergistic effects \\
\hline BMPs & $\begin{array}{l}\text { Induction of nervous system } \\
\text { Floor plate induction (BMP- } \\
4 \text { and BMP-7) } \\
\text { Oligodendrogenesis } \\
\text { (BMP-2/BMP-4) } \\
\text { Neurogenesis in olfactory } \\
\text { epithelium }\end{array}$ & $\begin{array}{l}\text { Roof plate induction (BMP-4 and BMP-7) } \\
\text { Anterior neural tissue specification (BMP-5 and BMP-7) } \\
\text { Dorsoventral patterning of the nervous system (BMP-4, BMP-6, } \\
\quad \text { and BMP-7) } \\
\text { Neurogenesis (BMP-2, BMP-4, and BMP-6) } \\
\text { Astrocytogenesis (BMP-2 and BMP-4) } \\
\text { Cholinergic neuron specification (BMP-9) } \\
\text { Guidance of commissural axons (BMP-7) } \\
\text { Dendritic growth } \\
\text { Neuronal migration } \\
\text { Induction of neurotrophin dependence } \\
\text { Apoptosis of stem/progenitor cells }\end{array}$ \\
\hline Nodal & Induction of nervous system & $\begin{array}{l}\text { Induction of floor plate } \\
\text { Differentiation of hypothalamic neurons }\end{array}$ \\
\hline Activins & Induction of nervous system & Specification of rod photo receptors \\
\hline GDFs & $\begin{array}{l}\text { Neurogenesis in olfactory } \\
\text { epithelium (GDF-11) }\end{array}$ & $\begin{array}{l}\text { Specification of dorsal neurons (GDF-7) } \\
\text { Neurogenesis in olfactory epithelium (GDF-7) } \\
\text { Guidance of commissural axons (GDF-7) }\end{array}$ \\
\hline TGF- $\beta s$ & $\begin{array}{l}\text { Microglial activation } \\
\quad(\text { TGF- } \beta 1)\end{array}$ & $\begin{array}{l}\text { Neurotrophic for dopaminergic and Purkinje neurons (TGF- } \beta 2 \\
\text { and TGF- } \beta 3 \text { ) } \\
\text { Neuronal differentiation in olfactory epithelium (TGF- } \beta 1 \text { and } \\
\text { TGF- } \beta 2 \text { ) } \\
\text { Differentiation of oligodendrocytes } \\
\text { Neuronal migration (TGF- } \beta 1 \text { and TGF- } \beta 2 \text { ) } \\
\text { Axon elongation (TGF- } \beta 1 \text { and TGF- } \beta 2 \text { ) } \\
\text { Synaptogenesis } \\
\text { Astrogliosis after injury (TGF- } \beta 1 \text { ) }\end{array}$ \\
\hline
\end{tabular}

Dan, Drm, Coco, and Ogon/Sizzled (sFRP) (Wagner and Mullins 2002; Yabe et al. 2003).

Targeted inactivation of any one neural inducer does not prevent formation of the CNS. For example, most mice have a normal CNS after inactivation of the Chordin gene (Bachiller et al. 2000; Anderson et al. 2002), and Noggin $^{-/-}$mice also have normal gastrulation and neural plate formation (McMahon et al. 1998). However, Chordin ${ }^{-/-}$; Noggin ${ }^{-1-}$ double-mutant mouse embryos have a severe neural phenotype with a loss of the prosencephalic vesicle and lack of anterior notocord, because of ventralization of the mesoderm (Bachiller et al. 2000). Similarly, antisense oligonucleotides targeting Noggin, Chordin, and Follistatin cause nearly complete loss of the neural plate in Xenopus tropicalis embryos (Khokha et al.
2005). Thus, chordin, noggin and follistatin have redundant functions in the BMP inhibition required for neural formation and patterning of the embryonic axis.

Nodal antagonists secreted from the organizer are also required to induce neural development. Although gastrulation is normal after targeted inactivation of expression of either of the nodal antagonists, Cerberus-like gene or Lefty1, Cerberus ${ }^{-/-}$; Lefty $1^{-/-}$double-mutant mice have severe developmental impairment of the anterior embryo (Perea-Gomez et al. 2002; Yamamoto et al. 2004). In Xenopus laevis, the asymmetry of nodal signaling is partially regulated by two microRNAs (miRNAs), miR15 and miR-16. These miRNAs are enriched at the ventral side of the embryo and attenuate the nodal signaling gradient by targeting the nodal 
TGF- $\beta$ and Neural Development

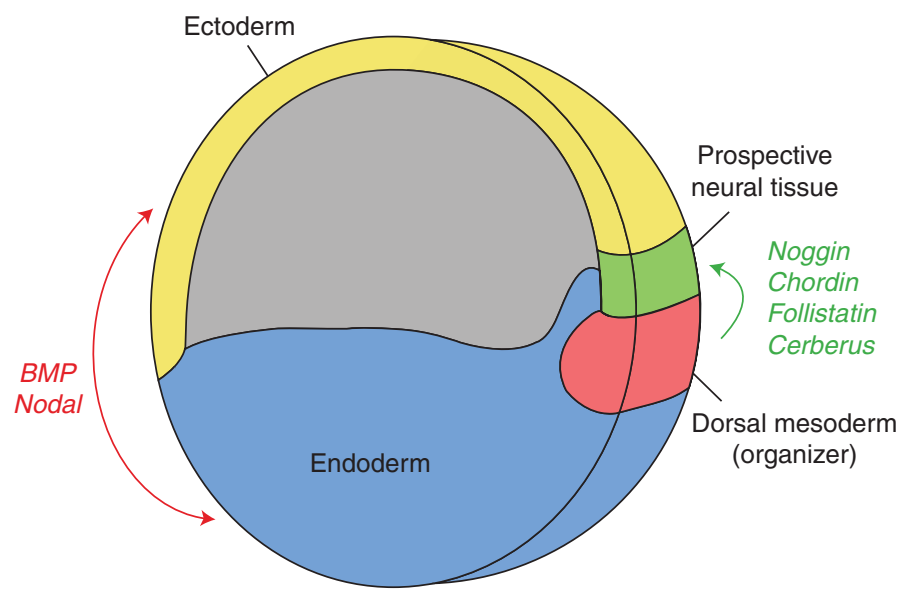

Figure 1. Role of the transforming growth factor- $\beta$ (TGF- $\beta$ ) family in neural induction. During late gastrulation, the neural tube is specified within ectoderm at the expense of epidermis. Bone morphogenetic proteins (BMPs) and nodal antagonists are secreted by the dorsal mesoderm (organizer) to allow for neural differentiation. BMP, nodal, and their cofactors are secreted from the ventral center to specify prospective epidermis.

receptor activin receptor type $2 \mathrm{~A}(\mathrm{ACVR} 2 \mathrm{~A}$, also known as ActRII) (Martello et al. 2007). Zebrafish use a different miRNA, miR-430, to target nodal signaling (Choi et al. 2007). Taken together, these studies identify a fundamental role for BMP and nodal signaling in neural induction and indicate that these families of antagonists act in a redundant or compensatory manner (Piccolo et al. 1999; Niehrs 2001; Wu and Hill 2009).

Epidermal fate is determined by the expression of the BMP-related Decapentaplegic (Dpp) in Drosophila and BMP-4 in Xenopus explants (Wilson and Hemmati-Brivanlou 1995). Numerous experimental methods have been used to impair BMP signaling, promoting neural induction of the epidermis (Hemmati-Brivanlou and Melton 1994; Hawley et al. 1995; Sasai et al. 1995; Wilson and Hemmati-Brivanlou 1995; Xu et al. 1995). Targeted silencing experiments for BMP-2, BMP-4, and BMP-7 in Xenopus indicate a redundancy in neural tissue specification; however, BMP-4 inhibition has the strongest dorsalized phenotype and is sufficient for neuralization (Reversade et al. 2005). Inactivation of BMP-2, BMP-4, and BMP-7 expression combined with inactivation of the expression of the BMP family member antidorsalizing morphogenetic protein (ADMP), which is expressed in the dorsal gastrula organizing center (Moos et al. 1995), causes complete neuralization of the ectoderm in Xenopus experiments. Restoring signaling by BMP-2, $-4,-7$ and/or ADMP in embryos with silenced BMP-2, BMP-4, and BMP-7 expression allows for an impressive return of epidermal patterning (Reversade and De Robertis 2005). Further, ADMP competes with nodal for the ACVR2A receptor, which may be a method for self-regulation in the organizer (Inui et al. 2012).

Manipulation of BMP signal transducers and inhibitors of downstream signaling further validates their roles in regulation of epidermal formation. Expression of Smad1 and Smad5, along with the BMP target gene Msxl prevents neuralization in Xenopus animal caps (Suzuki et al. 1997a,b; Wilson et al. 1997). Interfering with inhibitors of BMP signaling, for example, silencing the expression of the BMP decoy receptor BAMBI, the Smad ubiquitin ligase Smurf1, or the Smad4 E3 ubiquitin ligase ectodermin (also known as TIF1- $\gamma$ or TRIM33), impair neural induction (Onichtchouk et al. 1999; Zhu et al. 1999b; Dupont et al. 2005). Additionally, BMPs and their antagonists are regulated by extracellular metalloproteinases; specifically Twisted gastrulation (Tsg) binds both BMPs and chordin to modulate BMP sig- 
naling toward or against neural induction (Oelgeschläger et al. 2000, 2003; Larraín et al. 2001). This regulation is further complicated by expression of the Tolloid metalloproteinase that cleaves chordin, and Sizzled (sFRP) metalloproteinase, which inhibits Tolloid proteases (Oelgeschläger et al. 2003; Lee et al. 2006; Zakin and De Robertis 2010). Thus, inhibition of BMP signaling during neural induction is tightly regulated at many levels by BMP ligands, signal transducers, target genes, and extracellular metalloproteinases.

Wnt $/ \beta$-catenin signaling regulates the BMP pathway during early induction by inducing the expression of noggin and chordin in the dorsal organizer region. Activation of $\beta$-catenin signaling reduces BMP-4 expression leading to neurulation, which can be inhibited by a constitutively active BMPRIA (BMP type IA receptor, also known as ALK-3), linking both Wnt/ $\beta$-catenin and BMP signaling (Baker et al. 1999; Kuroda et al. 2004). BMP and Wnt signaling converge later in development when both signaling pathways are integrated through Smad1 phosphorylation of glycogen synthase kinase 3 (GSK3) in gastrulation (Fuentealba et al. 2007). In zebrafish, $\beta$-catenin induces a homeobox gene bozozok/dharma that directly represses the expression of BMP2b, which encodes BMP-4 (Leung et al. 2003). Bozozok ${ }^{-/-}$; Chordin ${ }^{-/-}$zebrafish mutants show synergistic losses of neural tissue and dorsal structures (Gonzalez et al. 2000). Taken together, Wnt $/ \beta$-catenin signaling acts to inhibit BMP transcripts and increase BMP antagonists to block their function and promote neural induction.

Additional signals regulate BMP activity to influence proper neural induction in the embryo (Lamb and Harland 1995; Fürthauer et al. 1997; Kretzschmar et al. 1997; Wilson et al. 2000; Pera et al. 2001). In particular, fibroblast growth factor (FGF) signaling down-regulates the expression of BMP-4 and BMP-7, and FGF together with insulin-like growth factor (IGF) activate the mitogen-activating protein (MAP) kinase cascade that regulates BMP signaling (Ishimura et al. 2000; Wilson et al. 2000). FGF and IGF obstruct BMP signal transduction by phosphorylating the linker region of Smad1 that blocks translocation of Smad to the nucleus (Pera et al. 2003; Sapkota et al. 2007). The relationship between BMP and FGF is necessary for proper neural development (Khokha et al. 2005); however, FGF signaling has additional roles in development of the embryo that are independent of BMP activity (Linker and Stern 2004; Delaune et al. 2005; Dorey and Amaya 2010).

In conclusion, loss- and gain-of-function experiments in multiple species show that antagonism of BMP signaling is required for proper induction of the nervous system. The importance of this signaling is further represented by the redundancy of BMP ligands and the need of double or triple knockdowns to fully elucidate the role of the TGF- $\beta$ family.

\section{NEURAL PATTERNING}

Following neural induction, organizing centers are responsible for patterning the complex structure of the nervous system (Fig. 2). The roof plate in the dorsal midline and the floor plate and notochord in the ventral midline establish dorsoventral identities. Proper development is induced by the TGF- $\beta$ family members nodal and BMP, whereas nodal signaling and BMP inhibition form the floor plate and specify ventral patterning. BMP signaling is instrumental in inducing the roof plate and specifying dorsal patterning (Placzek and Briscoe 2005; Lupo et al. 2006; Kiecker and Lumsden 2012).

Nodal signaling is crucial for proper formation and differentiation of the floor plate cells, as impairment of nodal signaling in the zebrafish mutant Cyclops and inhibition of nodal receptors yield severely depleted or absent floor plate cells (Hatta et al. 1991; Feldman et al. 1998; Rebagliati et al. 1998; Dougan et al. 2003). Malformation of the floor plate in the Cyclops mutant could be because of the effects on prechordal mesoderm differentiation that lead to a reduction in other signals, like sonic hedgehog (Shh). In Nodal ${ }^{-/-}$mutants, the floor plate is prematurely induced in the anterior epiblast in mouse embryos (Camus et al. 2006), whereas inactivation of the gene encoding the nodal antagonist Lefty increases induction of mesendoderm in formerly ectodermal tissue (Meno et al. 


\section{A}

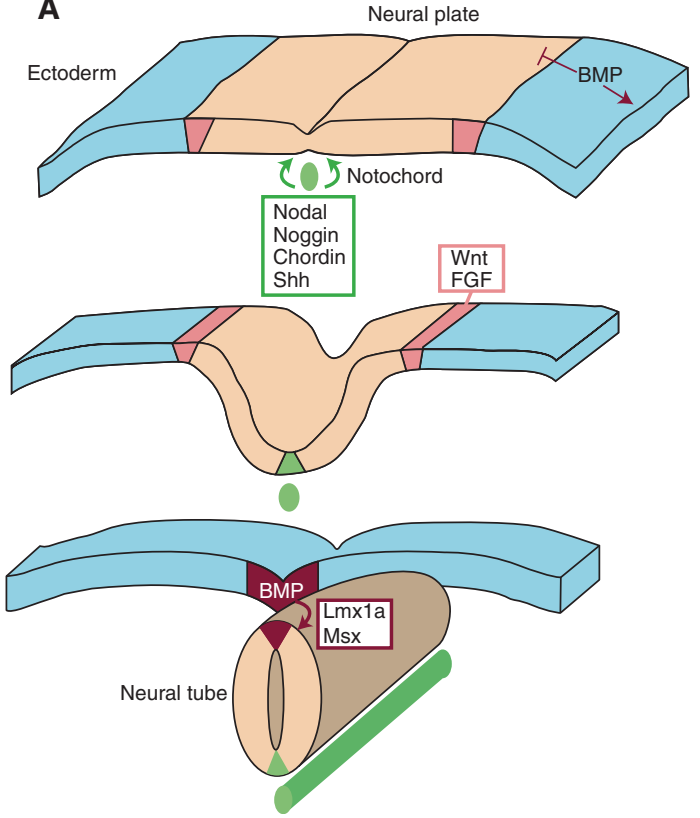

B

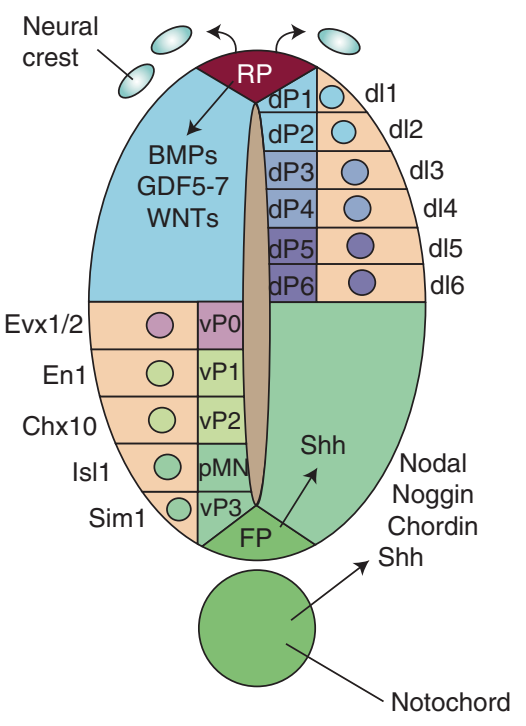

Figure 2. Role of the transforming growth factor- $\beta$ (TGF- $\beta$ ) family in forming the neural tube and patterning the spinal cord. (A) Antagonism from the notochord inhibits bone morphogenetic proteins (BMPs) signaling to specify the floor plate (FP) (green), whereas the neural plate folds to form the neural tube. The FP and roof plate (RP) (red) form on the ventral and dorsal midline of the neural tube, respectively. Wnt and fibroblast growth factor (FGF) help to regulate BMP signaling to aid in neurulation, and BMP signaling through Lmxla and Msx forms the RP. (B) BMPs, GDF-5, GDF-6, GDF-7, and Wnts are secreted from the RP to specify neural crest and dorsal interneuron ( $\mathrm{dI}$ ) subtype. Nodal and BMP antagonists are secreted from notochord to specify ventral neuron (vP) subtype. Nodal instructs ventral identity either in parallel or through sonic hedgehog (Shh) signaling.

1999; Perea-Gomez et al. 2002). Nodal-deficient mutants show late recovery of midline floor plate cells in the trunk and tail, identifying signaling pathways that ameliorate these effects, specifically Shh and Gli activity (Albert et al. 2003; Norton et al. 2005). This late recovery, however, is not observed in the brain. Variable cycloptic phenotypes are observed in $\mathrm{Nodal}^{-/+}$ mice, as well as heterozygous or homozygous mutants that inactivate downstream nodal signaling, including Smad2 or Acvr2a/Actr2 (Nomura and Li 1998; Song et al. 1999). Shh is required for floor plate development in many species (Chiang et al. 1996; Wijgerde et al. 2002), and nodal potentiates the ability of Shh to induce floor plate identity in addition to inducing the expression of ventral genes encoding Shh and the forkhead box A2 (FOXA2) transcription factor (Müller et al. 1999, 2000; Ras- tegar et al. 2002; Patten et al. 2003). Taken together, the role of nodal in ventral patterning may be to (1) sensitize cells to the action of Shh or to enhance Shh signaling (Chen and Schier 2001; Norton et al. 2005), (2) operate in parallel with Shh to trigger the expression of floor-plate-specific genes, or (3) foster expression of floor-plate-specific genes, including $S h h$, that require Shh for their maintenance (Norton et al. 2005).

In addition to nodal activation, inhibition of BMP signaling is required for proper floor plate induction. Noggin, chordin, and follistatin are expressed in the notochord, prechordal mesoderm, and floor plate that extends from the presumptive anterior diencephalon into the hindbrain (Furuta et al. 1997; Dale et al. 1999; Chapman et al. 2002). Impairments in Shh-expressing ventral midline cells are ob- 
served in Noggin ${ }^{-1-}$ mutant mice (McMahon et al. 1998), whereas the combined actions of Shh and Chordin are able to induce ectopic Shh-expressing floor plate cells in the chick embryo in vivo (Patten and Placzek 2002). Chordin $^{-/-} ;$Noggin $^{+/-}$mice have a dorsalized ventral telencephalon (Anderson et al. 2002), and similar phenotypes are observed in mice lacking Megalin/Lrp2, which encodes a protein responsible for endocytic uptake and lysosomal degradation of BMP-4 (Spoelgen et al. 2005). Further, Bmprla ${ }^{-1-} ; B_{m p r l b}{ }^{-1-}$ mice fail to form two hemispheres, known as holoprosencephaly, and also fail to form the dorsal midline cell types (Fernandes et al. 2007). Taken together, inhibition of BMP signaling, together with nodal and Shh signaling, is required for proper induction of the floor plate.

Following formation of the floor plate, inhibition of BMP signaling induces normal ventralization of the neural tube (Fig. 2B). This is observed in Noggin ${ }^{-1-}$ mice, which results in the loss of ventral interneurons and depletion of motor neurons (McMahon et al. 1998; Liem et al. 2000), whereas overexpression of chordin and follistatin expands the motor neuron population at the expense of dorsal populations (Liem et al. 2000; Patten and Placzek 2002). Localized inhibition of BMP signaling confines expression during patterning. The homeodomain protein, Six 3 , represses BMP-4 expression in the forebrain near the anterior neural plate and is able to restore the size of neural plate in Chordin $^{-/-}$mice (Gestri et al. 2005). Meanwhile, Smad7, an inhibitory-Smad, is expressed in the intermediate spinal cord and confines BMP signaling to the dorsal spinal cord (Yan et al. 2009; Hazen et al. 2011). Thus, control of BMP signaling in the spinal cord, through inhibition of signaling or repression of gene expression, is necessary for proper ventral patterning.

The roof plate forms along the dorsal midline of the neural tube and is induced by BMP signaling (Chizhikov and Millen 2004b). BMP-4 and BMP-7 are expressed in the chick epidermal ectoderm at the time of roof plate specification and can induce roof plate cells from cultured chick neural plate, whereas noggin and follistatin inhibit this induction (Liem et al. 1997).
$B m p 2, B m p 4$, and $B m p 7$ as well as Gdf7 (encoding GDF-7, growth and differentiation factor 7, also known as BMP-12), activin and dorsalin are expressed in the roof plate (Basler et al. 1993; Dickinson et al. 1995; Lee et al. 1998). BMP signaling is necessary and sufficient for chick roof plate development in vivo (Chizhikov and Millen 2004b; Liu et al. 2004) and ectopic activation of BMP signaling expands the roof plate domain to include almost the entire dorsoventral axis of the spinal cord. $B m p 5^{-/-}$; $B m p 7^{-/-}$double mutants develop an abnormally patterned forebrain, whereas $B m p 5^{-/-}$or $B m p 7^{-/-}$single mutants do not show developmental defects in the brain (Solloway and Robertson 1999). These studies show the crucial role of the TGF- $\beta$ family, particularly BMP signaling, in the development of the dorsal organizer.

BMP signaling activates expression of LIM and Msx homeodomain transcription factors to induce the roof plate. Gain- and loss-of-function experiments in chick and mouse models show that expression of Lmxla is activated by BMP signaling from epidermal ectoderm (Millonig et al. 2000; Chizhikov and Millen 2004a). Interestingly, Lmxla induces expression of Gdf7/ Bmp12 and Bmp4 when ectopically expressed in the developing chick spinal cord or in caudal neural tube explants in vitro (Chizhikov and Millen 2004a). Lmx1a is the main regulator of BMP signaling, as BMP-4 is unable to induce roof plate in explants from $L m \times 1 a^{-/-}$mutants. By itself, Lmxla can induce roof plate only in the most dorsal region of the neural tube, suggesting that cofactors are necessary for its dorsalizing effects (Chizhikov and Millen 2004a; Liu et al. 2004). These observations indicate a feedback regulation of BMP and Lmxla signaling. BMP signaling also induces the expression of the Msx family transcription factors $(M s \times 1, M s \times 2$, and Msx3) in the dorsal spinal cord (Timmer et al. 2002; Liu et al. 2004). Single loss-of-function studies have not been informative, likely because of redundancy; however, overexpression of Msx1, but not $M s \times 3$, in early chick developing spinal cord is sufficient to induce expression of roof plate markers (Liu et al. 2004). Together, Msx and Lmxla mediate aspects of BMP signaling effects on roof plate development. 
After specifying the roof plate, BMP signaling acts as a morphogen to pattern specific dorsal subtypes in a posterior-caudal to anterorostral direction (for review, see Chizhikov and Millen 2005). BMP signals induce interneuron populations in the dorsal (dI1-dI3), but not more ventral (dI4-dI6) spinal cord (Liem et al. 1995, 1997). Addition of BMP-4, BMP-6, BMP7 , or GDF-7 to naïve caudal neural plate explants mimics roof-plate-mediated induction of dI1 and dI3 interneurons (Liem et al. 1997; Lee et al. 1998; Butler and Dodd 2003), and complete ablation of the roof plate results in failure to form dI1-dI3 interneurons leading to expansion of dI4-dI6 interneurons (Lee et al. 2000). Deletion of both BMPRIA and BMPRIB from the dorsal spinal cord leads to a complete loss of the dorsal-most dI1 interneurons (WineLee et al. 2004), whereas activation of BMPRIA and BMPRIB expands dII interneurons at the expense of other interneuron types (Timmer et al. 2002; Chizhikov and Millen 2004a; Liu et al. 2004). Use of small interfering RNA (siRNA) to silence the expression of the downstream BMP signaling mediator, Smad4, has similar effects on dorsal phenotypes (Chesnutt et al. 2004). Thus, BMP signaling is necessary for patterning of dorsal interneurons, and this role is mediated in part by Lmx1a and Msx3 (Millonig et al. 2000; Chizhikov and Millen 2004a; Liu et al. 2004).

Beyond the spinal cord, BMP signaling from the roof plate contributes to the development of the dorsal hindbrain and diencephalon. Hindbrain roof plate cultures express Bmp6, Bmp7, and $G d f 7$ and these factors are sufficient to induce cerebellar granule neurons (Alder et al. 1999; Machold et al. 2007). BMP-4 and BMP-6 stimulate differentiation and promote survival of granule neurons (Angley et al. 2003; BarnedaZahonero et al. 2009), whereas targeted inactivation of Bmprla and Bmprlb in mice results in fewer cerebellar granule neurons, causing a smaller cerebellar cortex without foliation (Qin et al. 2006). Application of noggin to the developing midbrain-hindbrain border results in complete loss or dorsal shift of Phox2-positive neurons. The varying response of Phox2positive neurons indicates that they form in response to a graded BMP signal from either the roof plate or adjacent epidermal ectoderm (Vogel-Höpker and Rohrer 2002). Downstream BMP signaling through Lmxla plays a unique role in segregating roof plate epithelium lineage from adjacent cerebellar rhombic lip cell lineage. $L m \times 1 a^{-/-}$mouse embryos induce the roof plate normally; however, cells that belong to the roof plate epithelium lineage migrate and adopt fates of neuronal rhombic lip derivatives (Chizhikov et al. 2010). Msxl signals downstream of BMP in the more rostral roof plate, and targeted inactivation of $M s x 1$ causes a specific loss of the diencephalic roof plate and compromises the dorsal subcommissural organ (Bach et al. 2003). Expression of BMP ligands and receptors both dorsally and ventrally in the diencephalon enhances the complexity of this signaling pathway. Activation of BMPRIA and BMPRIB results in a disruption of proper gene expression patterns in the diencephalon, in addition to an increase in programmed cell death (Lim et al. 2005). However, dominant-negative BMPRIA and BMPRIB did not perturb diencephalic nuclear patterning, suggesting that signaling via BMPRI receptors may not be necessary for patterning in the diencephalon. Thus, BMP signaling functions as a dorsalizing factor in the hindbrain to specify the cerebellum as well as in the spinal cord.

The cerebral hemispheres of the telencephalon surround and dwarf the dorsal midline (roof plate) as it differentiates into the choroid plexus and cortical hem. The dorsomedial telencephalon expresses BMP-2, BMP-4, BMP-6 and BMP-7, as well as the BMP target genes Msx1 and Msx2 (Furuta et al. 1997; Grove et al. 1998). Ablation of the roof plate fails to induce the dorsal telencephalic midline tissue, and gene expression is reduced, including diminished adjacent Lhx2 expression (Monuki et al. 2001; Cheng et al. 2006). Similarly, inactivation of BMP signaling leads to specific loss of the roof-plate-derived choroid plexus, and the cortical hem fails to form (Hébert et al. 2003; Fernandes et al. 2007). Expression of activated BMPRIA in the telencephalon or ectopic expression of BMP-4 can rescue the choroid plexus epithelium without affecting the ventral 
neural tube (Hébert et al. 2002; Cheng et al. 2006). When BMP signaling is ablated after neural tube closure, holoprosencephaly does not occur, but formation of the dentate gyrus of the hippocampus is affected (Caronia et al. 2010). Indirect evidence suggests a larger role for BMP signaling in the telencephalon. Mutual antagonism exists between BMPs and Wnts in the cortical hem and between BMPs and FGF-8 in the anterior telencephalon. Additionally, there are significant forebrain patterning defects in embryos treated with exogenous BMPs, mice lacking both $B m p 5$ and $B m p 7$, and mice lacking Chordin and Noggin (Bachiller et al. 2000). These models are complicated to interpret because they include phenotypes that span multiple regions beyond the roof plate. Thus, understanding the role of BMP signaling in telencephalon patterning (and all patterning along the anterior-posterior axis) must be seen in the context of other signaling cascades and transcriptional networks. However, in general BMP signaling specifies dorsal structures, and its role in ventral instruction is less well known.

\section{CELL FATE SPECIFICATION}

Stem and progenitor cells in the proliferative ventricular zone (VZ) and later the subventricular zone (SVZ) generate neurons throughout the CNS, followed by sequential waves of astrocyte and oligodendroglia generation. Remarkably, BMP signaling is critical for progenitor cell fate specification in both neurogenesis and astrogliogenesis, although it inhibits oligodendrogliogenesis at all stages of development.

\section{Neurons}

\section{Forebrain}

Neural stem cells in the VZ and SVZ have the potential to differentiate into all major neural cell types, and the influence of BMP signaling on lineage commitment shifts during development. At early stages of neurogenesis, exposing stem cells and progenitor cells in the telencephalic VZ to BMP-2 or BMP-4 increases apoptosis and inhibits proliferation, whereas at later stages BMP-2 or BMP-4 signaling promotes neuronal differentiation by inducing the expression of the neuron-specific class II $\beta$-tubulin (Tuj1) through activation of the Erk mitogenactivated protein kinase (MAPK) pathway (Li et al. 1998; Mabie et al. 1999; Mehler et al. 2000; Moon et al. 2009). Forebrain explants exposed to BMP-4 downregulate anterior neural gene expression, and deletion of BMP antagonists causes loss of anterior brain structures (Furuta et al. 1997; Anderson et al. 2002). BMPs are strong inducers of both $I d$ and Hes family members, which inhibit actions of basic helix-loop-helix (bHLH) transcription factors (Ross et al. 2003) and mediate many of the negative effects of BMPs on commitment and differentiation of neuronal precursors (Takizawa et al. 2003; Imayoshi et al. 2008). The peak of expression of neurogenin (Ngn1), a proneuronal bHLH transcription factor, coincides with the time course of neurogenesis and gradually declines with the transition to gliogenesis (Ma et al. 1996). During neurogenesis, Ngn1 suppresses BMP-mediated astrocyte differentiation by sequestering downstream transcriptional regulators away from glial gene promoters, such as the promoter of the gene encoding glial fibrillary acid protein (GFAP) (Sun et al. 2001). BMP-2 expression in the VZ results in differentiation and migration of neuroblasts away from the VZ (Li et al. 1998). It also promotes survival and differentiation of cultured FGF-2-primed ventral progenitor cells of the SVZ into GABAergic striatal neurons (Hattori et al. 1999; Yung et al. 2002).

Further cell-type specification is guided by BMP expression, where a balance between BMP4 and Shh is necessary for determining the proportion of interneurons generated in vivo. This is evident in the greater number of GABAergic interneurons that are derived from progenitor cells in the dorsolateral versus the dorsomedial wall of the telencephalon, where BMP expression is highest (Furuta et al. 1997; Mehler et al. 1997; Grove et al. 1998). Exogenous Shh expression in the dorsomedial wall enhances the number of GABAergic interneurons (Gulacsi and Lillien 2003), whereas BMP signaling determines the fate of GABAergic interneuron pre- 
cursors, promoting differentiation of parvalbumin-positive interneurons and blocking differentiation of calbindin- and somatostatinpositive interneurons (Samanta et al. 2007; Mukhopadhyay et al. 2009). Induction of basal forebrain cholinergic neurons (BFCNs) requires BMP-9 expression (López-Coviella et al. 2000, 2005) and, interestingly, human embryonic stem-cell cultures confirm that BMP-9 induces expression of transcription factors that are necessary and sufficient for BFCN induction (Bissonnette et al. 2011).

BMP signaling continues to regulate neurogenesis in two niches of the adult telencephalon that maintain populations of neural stem cells, the SVZ in the lateral ventricles, and the subgranular zone (SGZ) of the hippocampus. BMP-2, BMP-4, and BMP-7 are expressed in the SVZ and promote astroglial lineage commitment, whereas noggin suppresses it (Lim et al. 2000; Colak et al. 2008). In the SGZ, exogenous expression of noggin and BMP-4, or inactivation of either BMPRIA or Smad4 show the role of BMP signaling in the regulation of quiescence and activation of neural stem cells (Bonaguidi et al. 2008; Colak et al. 2008; Mira et al. 2010; Bond et al. 2014; Meyers et al. 2016).

\section{Midbrain}

The TGF- $\beta$ family regulates development of dopaminergic neurons (DNs) in the substantia nigra, the neuronal population that degenerates in Parkinson's disease. TGF- $\beta$ and Shh cooperatively induce DNs from ventral midbrain floor cells in vitro and in chick embryo in vivo (Krieglstein et al. 2000; Farkas et al. 2003; Roussa and Krieglstein 2004), whereas $\mathrm{Tgfb2}^{-/} ; \mathrm{Tgfb3}^{-/-}$mice have a severe reduction in DNs at E14.5 (Roussa et al. 2006). Glialderived neurotrophic factor (GDNF) promotes survival of embryonic DNs and inhibits the apoptotic death in postnatal midbrain DNs in vitro (Apostolides et al. 1998; Burke 2003). Together, TGF- $\beta 2$ and TGF- $\beta 3$ synergize with GDNF to facilitate its signaling (Peterziel et al. 2002), whereas TGF- $\beta$ neutralizing antibodies abolish the survival-promoting effects of GDNF in vitro and in vivo (Krieglstein et al. 1998;
Schober et al. 2007). GDF-5 (also known as BMP-14 and CDMP-1) expression occurs during differentiation of DNs in the ventral midbrain and increases the number of DNs in E14 rat ventral midbrain cultures (Krieglstein et al. 1995b; Wood et al. 2005; O'Sullivan et al. 2010). GDF-5 and GDF-15 (also known as NAG-1 and MIC-1) promote adult DN survival and GDF-5 further increases neurite growth from $\mathrm{DNs}$ in ventral midbrain transplants into adult striatum (Sullivan et al. 1998; O'Sullivan et al. 2010; Costello et al. 2012). GDNF-deficient mice show normal DN development; however, Gdnf ${ }^{/-}$; $\mathrm{Tgfb} 2^{-/-}$mice show a loss in midbrain DNs at E14.5 (Roussa et al. 2008; Rahhal et al. 2009).

\section{Hindbrain}

Mice lacking expression of both $B m p 5$ and $B m p 7$ have delayed closure of the cranial neural tube and the size of the hindbrain roof plate is compromised (Solloway and Robertson 1999), whereas ectopic expression of Bmp7 in the hindbrain causes dorsalization and expansion of the hindbrain neuroectoderm (Arkell and Beddington 1997). Cerebellar granule neurons originate in the rhombic lip and many BMPs, including BMP-6, BMP-7, and GDF-7, are expressed in the midline cells adjacent to the rhombic lip and induce cerebellar granular progenitors in vitro (Alder et al. 1999). Conditional Bmpr1a $a^{-/-}$; Bmpr1b $b^{-/-}$mutants show a dramatic repression of granule cell specification markers along with a loss in the number of granule neurons, whereas the number of Purkinje cells remains unaltered in vivo (Qin et al. 2006). Purkinje and granule cells in the cerebellum express TGF- $\beta 2$, which regulates the proliferation of cerebellar neurons in vitro (Constam et al. 1994; Kane et al. 1996). Down-regulation of TGF- $\beta$ family signaling by a reduction in Smad4 during embryogenesis is required for proper temporal and spatial development of granule progenitor cells (Fernandes et al. 2012). However, inactivation of Smad4 in the mouse CNS results in a marked decrease in the number of Purkinje cells and parvalbumin-positive interneurons in the cerebellum (Zhou et al. 2003). Taken together, members of the TGF- $\beta$ family 
directly regulate various cell types in the cerebellum.

\section{The Retina and Olfactory Epithelium}

TGF- $\beta 2$ and TGF- $\beta 3$ are expressed in the central retina but are restricted to the zones of optic nerve head and optic fiber layer, whereas the TGF- $\beta$ type I and TGF- $\beta$ type II receptors (T $\beta R I$ and T $\beta$ RII) are expressed in the inner retina, cornea and lens (Dünker and Krieglstein 2003). $\mathrm{Tg} f b 2^{-/-}$mice show inhibition of apoptosis in the neuroblastic layers of the retina, whereas $\mathrm{Tg} f \mathrm{b3}^{-/-}$mice show no phenotype in the eye (Kaartinen et al. 1995; Proetzel et al. 1995; Sanford et al. 1997; Dünker et al. 2001). However, $\mathrm{Tgfb2} 2^{-1-}$; $\mathrm{Tg} f b 3^{-/-}$mice have their retina detached from the underlying pigment epithelium along with a dose-dependent reduction in the thickness of the cornea, the corneal stroma, and the lens epithelium, resulting from enhanced apoptosis (Dünker and Krieglstein 2003).

TGF- $\beta$ family members exert both positive and negative regulation of olfactory receptor neuron differentiation. BMP-4 and BMP-7 are expressed by embryonic neurons in the olfactory epithelium, whereas BMP-2 is expressed by stromal fibroblasts (Shou et al. 2000; Peretto et al. 2002). Olfactory epithelial cell cultures treated with BMP-2, BMP-4, or BMP-7 reduce olfactory receptor neurons (Shou et al. 1999), whereas low concentrations of BMP-4 in vitro promote survival of newly generated olfactory receptor neurons (Shou et al. 2000). These opposing effects are likely controlled by activation of different receptors. Inactivation of Bmprlb prevents the reduction of neurogenesis induced by BMP-7, whereas the effects of BMP-4 remain unaltered (Calof et al. 2002). Both BMPRIA and BMPRIB are expressed in the olfactory epithelium and, whereas BMP-4 and BMP-7 signal through BMPRIB, BMP-4 signals through BMPRIA (ten Dijke et al. 1994), suggesting that BMPRIA exerts a survival effect. Neurogenesis in olfactory epithelial cell cultures is stimulated by GDF-7, and targeted inactivation of Gdf7 reduces the number of MASH1-positive progenitor cells (Kawauchi et al. 2004). GDF-11 (also known as BMP-11), its receptors, and its antagonist follistatin, are expressed by progenitors and olfactory receptor neurons in the olfactory epithelium. GDF-11 is a negative growth regulator of olfactory receptor neurons and impairs proliferation of neuronal precursors, whereas follistatin reverses this effect (Wu et al. 2003; Lander et al. 2009; Gokoffski et al. 2011). Thus, the TGF- $\beta$ family regulates persistent neurogenesis in the adult olfactory system, stimulating production of olfactory receptor neurons when necessary.

\section{Astrocytes}

During late embryonic and postnatal periods, BMP signaling strongly induces astrocyte differentiation (Gross et al. 1996; Mehler et al. 1997; Fukuda et al. 2007; See et al. 2007). In culture, BMP signaling promotes astrogliogenesis in SVZ progenitor cells, cortical progenitor cells, and oligodendrocyte precursor cells (Gross et al. 1996; Mabie et al. 1999; Grinspan et al. 2000). In the adult brain, BMP signaling promotes astroglial lineage commitment and blocks neuron and oligodendrocyte differentiation, whereas noggin suppresses the number of stellate astrocytes (Gomes et al. 2003a). Cultured neural stem cells express the astrocyte intermediate filament protein, GFAP, in response to the leukemia inhibitory factor (LIF)/ciliary neurotrophic factor (CNTF) family proteins as well as BMPs. LIF/CNTF proteins, which activate Jak-STAT pathways, cooperate with BMPs to promote astrogliogenesis by activating the expression of astrocyte-specific genes through a STAT3-p300/CBP-Smad1 complex (Nakashima et al. 1999). Because induction of GFAP-expressing cells through LIF and BMP signaling acts through different pathways, this may explain in part why LIF and BMP generate different types of astrocytes. LIF-induced astrogliogenesis generates more immature GFAPpositive progenitor cells, whereas BMP signaling promotes more mature GFAP-positive astrocytes that lack stem/progenitor cell properties (Bonaguidi et al. 2005). BMP-mediated astroglial fate commitment can also occur by noncanonical STAT signaling through the serine-thre- 
onine kinase FKBP12/rapamycin-associated protein (FRAP), also known as mammalian target of rapamycin (mTOR), in high-density conditions (Rajan et al. 2003). In this signaling pathway, FKBP12 binds to BMPRIA and after BMP-4 binding, detaches to activate FRAP, which in turn phosphorylates STAT causing astrocytic gene expression. Recent studies have identified the histone acetylation/deacetylation machinery as the means through which BMP and STAT3 promote astrocytic differentiation (Scholl et al. 2012). TGF- $\beta 2$ and TGF- $\beta 3$, as well as their receptors, are expressed in astrocytes, and TGF- $\beta 1$ expression is induced in astrocytes, in culture of after injury (ToruDelbauffe et al. 1990). Thus, whereas BMPs are required for specification of astrocytes, a role for TGF- $\beta$ s in astrocytes is primarily linked to neural injury.

\section{Oligodendrocytes}

Oligodendrocyte differentiation occurs in the subcortical white matter, whereas BMP signaling is inhibited by noggin ( $\mathrm{Li}$ et al. 1998; Mabie et al. 1999). In early embryogenesis, inactivation of BMP signaling in the chick dorsal neural axis results in an increase in oligodendrogenesis (Mekki-Dauriac et al. 2002). BMP-2 or BMP-4 treatment of cultured neural stem/progenitor cells inhibits oligodendrogenesis at all stages of development, whereas noggin treatment increases it (Mehler et al. 1995; Gross et al. 1996; Zhu et al. 1999a). Diminished oligodendrocyte differentiation is also observed in transgenic mice overexpressing BMP-4, whereas overexpression of noggin increases oligodendrogenesis (Gomes et al. 2003b). BMPs regulate oligodendrogenesis through up-regulation of the expression of Id 2 and Id 4 in neural progenitors, which sequesters Olig1 and Olig2, preventing them from binding to their targets (Samanta and Kessler 2004). BMP signaling may also have a role in myelin protein expression, as seen in myelin injury and disease models (See and Grinspan 2009; Weng et al. 2012). In contrast, noggin treatment increases the number of mature oligodendrocytes and increases remyelination of injured axons in the corpus callosum (Sabo et al. 2011; Wu et al. 2012; Sabo and Cate 2013). Further, Sip1 (Smad-interacting protein 1, also known as Zeb2) has been identified as an essential modulator of myelination through transcriptional repression of downstream BMP signaling (Weng et al. 2012). It should be noted that oligodendrocyte precursors also express TGF- $\beta$, and that the combination of TGF- $\beta$ and activin signaling promotes oligodendrogenesis and CNS myelination (McKinnon et al. 1993; Dutta et al. 2014).

\section{Microglia}

Microglia are quiescent macrophages that are activated in response to injury and disease in the CNS. Microglia synthesize and secrete TGF- $\beta 1$ in response to inflammatory cytokines such as type I interleukin (IL-1), IL-6, nerve growth factor (NGF) and tumor necrosis factor- $\alpha$ (TNF- $\alpha$ ) (Lindholm et al. 1992b; da Cunha et al. 1993; Chao et al. 1995a,b). TGF$\beta 1$ inhibits free radical induction and induces apoptosis, and TGF- $\beta$ signaling through Smad 2 and/or Smad3 is necessary for maintaining quiescent microglia populations after injury (Suzumura et al. 1993; Lodge and Sriram 1996; Herrera-Molina and von Bernhardi 2005; Abutbul et al. 2012). Extensive microgliosis is observed in the neocortex and hippocampus in $T g f b 1^{-/-}$mice, whereas one allele of $T g f b 1$ is sufficient to reverse the phenotype (Brionne et al. 2003). These studies identify TGF- $\beta 1$ as an anti-inflammatory cytokine in the CNS through inactivation of microglia.

\section{MIGRATION AND AXON GUIDANCE}

Following neurogenesis, the formation of cell layers in the nervous system depends on interactions between neurons, glia, and the extracellular matrix for spatial and temporal migration. The expression patterns of TGF- $\beta$ ligands and receptors in the cerebral cortex are indicative of their involvement in neuronal migration. TGF$\beta 1$ is primarily expressed in the meninges, TGF$\beta 2$ and TGF- $\beta 3$ are expressed by neurons and radial glia, and BMP-6 is expressed by radial glia (Schluesener and Meyermann 1994; Murphy 
et al. 2004; Ozdamar et al. 2005). TßRI is expressed in the developing murine cortex, and is found postnatally along radial glial fibers, whereas T $\beta$ RII is primarily expressed by neurons (Tomoda et al. 1996; Miller 2003). Low concentrations of TGF- $\beta 1$ in culture promote neuronal migration of immature neurons and neuroblastoma cells, whereas high concentrations impair migration. TGF- $\beta 1$ acts by upregulating the expression of cell-adhesion molecules, like neural cell-adhesion molecule (N-CAM), and the integrin subunits $\alpha_{3}, \alpha_{5}$, and $\beta_{1}$ (Siegenthaler and Miller 2004). Celladhesion molecules assist in cell migration by mediating cell attachments through hemophilic interactions, and integrins act as essential links between the extracellular environment and cytoskeleton. In glioma brain tumors, TGF- $\beta 1$ and TGF- $\beta 2$ stimulate migration of glioma cells by inducing the expression of $\alpha 5 \beta 3$ integrins, whereas anti-TGF- $\beta$ neutralizing antibodies reduce glioma cell migration (Paulus et al. 1995; Platten et al. 2000; Wick et al. 2001). TGF- $\beta 1$, TGF- $\beta 2$, and TGF- $\beta 3$ have also been shown to increase the number and length of neurites (Unsicker et al. 1996). Together, these findings indicate that TGF- $\beta$ signaling is required to induce axon formation and neuronal migration (Yi et al. 2010).

BMP and activin are responsible for migration and axon guidance in the developing brain. BMPs act as inductive signals to promote growth cone guidance, axonal orientation and path finding. During spinal cord development, BMP-6, BMP-7, and GDF-7 are expressed in the rodent roof plate and direct commissural neuron axon extension through the spinal cord toward the floor plate (Lee et al. 1998; Augsburger et al. 1999; Butler and Dodd 2003). Explant cultures treated with BMP-7 mimic the repellent activity of the roof plate for commissural axons and directly act to collapse their growth cones (Augsburger et al. 1999), whereas $B m p 7^{-/-}$ and $G d f 7^{-/-}$explant cultures show very little repellent activity in vitro. Studies show that BMP-7 and GDF-7 form a heterodimer and act cooperatively in vivo for the guidance of commissural axons (Butler and Dodd 2003). Interestingly, BMP-6 and BMP-7 both induce differentiation of commissural neurons, but only BMP-7 is necessary to orient axons (Perron and Dodd 2011, 2012). The fast-acting repellent action of BMP-induced axonal orientation suggests signaling through cytoskeletal actin remodeling and c-Jun amino-terminal kinase (JNK)-mediated microtubule stabilization (Wen et al. 2007; Podkowa et al. 2010; Perron and Dodd 2011). Additional signaling from activin aids in organizing neural circuitry, and the expression of the activin $\beta$ A subunit at E17 in the telencephalon indicates a possible role in topographical wiring between the neocortex and neostriatum (Andreasson and Worley 1995). In vitro cultures of rat cortical neurons show that activin signaling promotes dendritic complexity through disinhibiting specific signaling factors (Ishikawa et al. 2010). Thus, multiple members of the TGF- $\beta$ family are highly involved in migration and axon outgrowth and guidance.

\section{SYNAPTOGENESIS AND PLASTICITY}

Neurons communicate through synapses that allow for two-way signal transmission from presynaptic and postsynaptic targets. Strengthening synapses is necessary for learning and memory and for regenerating neuronal circuits after injury. BMP signaling regulates neurite outgrowth and dendritic development throughout the CNS, including cortical neurons ( $\mathrm{Li}$ et al. 1998; Le Roux et al. 1999; Lee-Hoeflich et al. 2004; Podkowa et al. 2010), hippocampal neurons (Withers et al. 2000), and cerebellar neurons (Matsuura et al. 2007). In culture, treatment of sympathetic neurons with BMP-2, BMP-5, BMP-6, or BMP-7 enhances dendritic development (Lein et al. 1995, 1996; Guo et al. 1998; Beck et al. 2001; Horbinski et al. 2002). However, in cerebellar granule neurons, BMP-2 inhibits neurite outgrowth by LIMK-dependent mechanisms (Matsuura et al. 2007). Treatment of cultured rat hippocampal neurons with TGF$\beta 1$ or TGF- $\beta 2$ results in extension of axon-like processes with no effect on dendritogenesis (Ishihara et al. 1994). The postulated role of TGF- $\beta$ in synapse formation and plasticity in vertebrates is based to a large extent on expres- 
sion patterns. Inactivation of $T g f b 1$ in mice results in lower levels of the presynaptic protein synaptophysin in the neocortex and hippocampus, leading to decreased synaptic density (Brionne et al. 2003). TGF- $\beta 1$ is also necessary for normal expression of the extracellular matrix protein laminin, which has been implicated in learning and memory (Venström and Reichardt 1993; Luckenbill-Edds 1997). Transgenic overexpression of TGF- $\beta 1$ in astrocytes leads to increased production of laminin, whereas loss of $T g f b 1$ results in a reduction in laminin expression (Brionne et al. 2003).

Direct evidence for the role of TGF- $\beta$ family proteins in synaptic differentiation and maturation comes from the study of the glutamatergic neuromuscular junction (NMJ) in Drosophila (for review, Darabid et al. 2014). Evidence of this involvement in synapse development and plasticity has also been provided by studies of the mollusk Aplysia (Schuman 1997; Zhang et al. 1997). During long-term sensitization of the gill- and siphon-withdrawal reflex in this organism, long-term facilitation also results in an increase in TGF- $\beta 1 \mathrm{mRNA}$ in sensory neurons (Liu et al. 1997; Zhang et al. 1997). Application of TGF- $\beta 1$ strengthens the sensorymotor-neuron synaptic connections, whereas a TGF- $\beta$ receptor antagonist blocks this effect (Zhang et al. 1997; Chin et al. 1999). In the mouse, TGF- $\beta 2$ treatment in cultured hippocampal neurons alters evoked postsynaptic currents (ePSCs), indicating a role in hippocampal synaptic plasticity (Fukushima et al. 2007). The TGF- $\beta$ family member activin also affects hippocampal neurons by modifying spine morphology and increasing synaptic contacts (Shoji-Kasai et al. 2007). Thus, the TGF- $\beta$ family has an important role in both synaptogenesis and in plasticity of the nervous system.

\section{CELL SURVIVAL AND DEATH IN THE NERVOUS SYSTEM}

Programmed cell death in the developing vertebrate nervous system is responsible for loss of a large number of neurons. Neuron survival is dependent on competition for a limited supply of survival factors (neurotrophins) provided by target cells. TGF- $\beta$ s are not independently neurotrophic; however, treatment with TGF- $\beta$ enhances neurotrophic signaling in cultured neurons grown with low and subthreshold concentrations of neurotrophins. Meanwhile, blocking endogenous TGF- $\beta$ s lowers the survival-promoting activity of neurotrophin (Krieglstein and Unsicker 1996; Krieglstein et al. 1998). The biological relevance of this synergy is also shown by the increase in TGF- $\beta$ synthesis and release from neurons in response to neurotrophins (Krieglstein and Unsicker 1996; Krieglstein et al. 1998). Unlike the cotrophic effects of TGF- $\beta$ signaling, BMP signaling in the developing nervous system triggers apoptosis. BMPs are expressed in the chick embryo in the dorsal regions of the odd-numbered rhombomeres (r3 and r5) and induce segmental apoptosis in these areas (Graham et al. 1994). Loss of BMP antagonists in Chordin ${ }^{-/-}$; Noggin ${ }^{+/-}$ embryos, as well as conditional activation of BMPRIA or BMPRIB expression, increases cell death in the rostral neuroepithelium (Anderson et al. 2002). BMP signaling induces apoptosis of neocortical progenitors, forebrain precursor explants, trigeminal neurons, sympathoadrenal cells, sympathetic neuroblasts, and postmigratory enteric neurons (Chalazonitis et al. 2004). In vitro, treatment of SVZ neurospheres with BMP-4 promotes apoptosis in a dose-dependent manner through Msx2 and the cyclin-dependent kinase inhibitor $\mathrm{p} 21^{\mathrm{Cip} 1}$ (Israsena and Kessler 2002). BMP signaling can also promote survival through indirect mechanisms such as induction of neurotrophin receptors (Zhang et al. 1998).

The TGF- $\beta$ family has an essential role in midbrain DN survival. TGF- $\beta 1$, TGF- $\beta 2$, and TGF- $\beta 3$ promote survival of mesencephalic DNs, whereas neutralizing antibodies against TGF- $\beta$ in the developing chick (E6-10) impairs survival (Krieglstein and Unsicker 1994; Poulsen et al. 1994; Roussa et al. 2004). The effects of TGF- $\beta$ signaling on DN survival are mediated by HIPK1 (homeodomain interacting protein kinase 1) interacting with Smad3 to regulate target genes (Zhang et al. 2007). In contrast, BMP signaling acts indirectly on dopaminergic neuron survival by stimulating astrocyte differ- 
entiation (Jordan et al. 1997; Farkas et al. 2003). BMP-7 induces dopamine neuron differentiation in culture, and promotes survival in the adult nigrostriatal pathway against dopamine toxins in vivo (Lee et al. 2003; Harvey et al. 2004; Chou et al. 2008). Although the direct role of BMP signaling on dopamine neuron induction is unknown, Msx1 and Lmxla are key determinants of midbrain DNs and are both induced by BMP-Smad activation (Tríbulo et al. 2003; Chizhikov and Millen 2004a; Andersson et al. 2006). Thus, TGF- $\beta$ s together with BMPs are key regulators in survival and programmed cell death within the developing nervous system.

\section{THE NORMAL AND PATHOLOGICAL ADULT NERVOUS SYSTEM}

Injury and Repair

The expression of several TGF- $\beta$ family ligands and receptors is increased following neural injury. In the normal adult rat brain TGF- $\beta 1$ is expressed at low levels primarily in the meninges; however, following brain injury, the expression of TGF- $\beta 1$ and the TGF- $\beta$ receptors, T $\beta$ RI

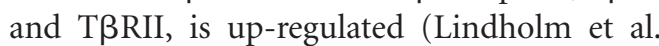
1992a; Tomoda et al. 1996; McTigue et al. 2000; Zhu et al. 2000; Sometani et al. 2001; Fee et al. 2004). The temporal pattern of TGF$\beta 1$ induction and neuronal death suggests that TGF- $\beta 1$ is predominantly expressed by activated microglia infiltrating the ischemic region (Lehrmann et al. 1995). TGF- $\beta 1$ expression increases following cerebral infarcts and spinal cord injury and mediates microglial activation to control inflammation following injury (Krupinski et al. 1996; Brionne et al. 2003; Makwana et al. 2007; Buss et al. 2008). A unique TGF- $\beta$ dependent population of microglia is present in both mouse and human (Butovsky et al. 2014), and treatment with TGF- $\beta 1$ before or within 2 hours after cerebral ischemia reduces the volume of infarct and neuronal death in several animal models (McNeill et al. 1994; Prehn and Krieglstein 1994; Henrich-Noack et al. 1996). However, in a neurodegenerative disease model, transgenic overexpression of TGF- $\beta 1$ in astrocytes exacerbates the disease pathology (Wyss-
Coray et al. 1997). In patients with multiple sclerosis, high levels of TGF- $\beta 1$ mRNA expression in mononuclear peripheral cells have been associated with reduced disability, disease duration, and disease brain activity (Link et al. 1994; Söderström et al. 1995; Bertolotto et al. 1999), although clinical trials of TGF- $\beta$ treatment of patients with multiple sclerosis were terminated because of non-neurological toxicity (Wiendl et al. 2000).

BMP signaling has been shown to promote astrocyte reactivity and glial scar formation after spinal cord injury. Expression of BMPs increases in the spinal cord after injury, and inhibition of BMP signaling in injured cords expands the lesion volume and shows poor functional recovery (Enzmann et al. 2005). However, there is evidence that BMP inhibition enhances axonal outgrowth and locomotor activity (Setoguchi et al. 2004; Matsuura et al. 2008). BMP receptor signaling following injury show a beneficial effect of BMPRIA, and not BMPRIB for wound repair (Sahni et al. 2010). $B m \operatorname{prlb}^{-/-}$mice have reduced lesion volumes and an increase in GFAP-expressing cells 1 week postinjury, whereas this result is not apparent in Bmprla ${ }^{-/-} ; \mathrm{Bmprlb}^{-/-}$mice. These results indicate a specific role of BMPRIA in the initial injury response; however, Bmprla $a^{-/-}$mice show better recovery 5 weeks postinjury, suggesting that BMPRIB regulates glial scar progression (Sahni et al. 2010). Further, miR-21, a posttranscriptional regulator of gene expression induced by BMP signaling, mediates the astrocytic response after spinal cord injury (Sahni et al. 2010; Bhalala et al. 2012). Thus, many members of the TGF- $\beta$ family have important roles following CNS injury, although these processes have yet to be fully understood.

\section{Neurodegenerative Diseases}

The TGF- $\beta$ family plays an extensive role in neurodegenerative diseases, injury and cancer. We will briefly discuss their roles in Alzheimer's and Parkinson's diseases, and amyotrophic lateral sclerosis pathologies (for further review, see Krieglstein 2013). 
Alzheimer's disease is a neurodegenerative disease characterized by the formation of senile plaques and neurofibrillary tangles in the cortex and limbic areas. Senile plaques are deposits of amyloid- $\beta$ (A $\beta)$ peptides generated by abnormally cleaved amyloid precursor protein (APP). TGF- $\beta 1$ contributes to $A \beta$ precursor expression and $A \beta$ deposition (van der Wal et al. 1993; Wyss-Coray et al. 1997; Burton et al. 2002); however, TGF- $\beta 1$ attenuates microglia clustering to $A \beta$ aggregates, and TGF- $\beta 1$ expression in astrocytes causes a reduction in overall plaque burden (Wyss-Coray et al. 2001; Huang et al. 2010). Interestingly, TGF- $\beta 1$ is enriched in plasma lipoprotein samples of apoliprotein E3 (apoE3), but occurs at a lower concentration in lipoproteins containing apoE4, a genetic risk factor for late-onset Alzheimer's disease (Tesseur et al. 2009; Bertram et al. 2010). Impairment in TGF- $\beta /$ Smad signaling and decreased neuronal expression of T $\beta$ RII are both characteristics of disease pathology, providing further evidence for a role for TGF- $\beta$ in $\mathrm{Alz}$ heimer's disease (Tesseur et al. 2006; Ueberham et al. 2006; Wang et al. 2010).

Utilizing the anti-inflammatory effects of TGF- $\beta$ as a treatment has been suggested as a possible therapy for Parkinson's disease, a disease in which midbrain DNs degenerate. TGF$\beta 2$ and TGF- $\beta 3$ are expressed in adult nigral DNs, and TGF- $\beta 1$ and TGF- $\beta 2$ expression is increased in biopsies of Parkinson's disease patients (Unsicker et al. 1991; Nagatsu et al. 2000). Treatment of DN cultures with TGF- $\beta 1$, TGF$\beta 2$, or TGF- $\beta 3$ enhances cell survival following exposure to the neurotoxin 1-methyl-4-phenyl1,2,3,6-tetrahydropyridine (MPTP), an experimental model of Parkinson's disease in vivo (Krieglstein et al. 1995a; Roussa et al. 2009). TGF- $\beta$ cooperates with GDNF, a potential therapeutic agent for Parkinson's disease, to promote DN survival (Krieglstein et al. 1998). Importantly, in the MPTP mouse model, GDNF-dependent neuroprotective effects are based on interaction with TGF- $\beta$ (Schober et al. 2007).

Amyotrophic lateral sclerosis (ALS) is a fatal disease characterized by paralysis caused by loss of motor neurons. A familial form of this disorder is the result of a mutation in superoxide dismutase 1 (SOD1). Because TGF- $\beta$ is a notable motoneuron survival factor (Martinou et al. 1990; McLennan and Koishi 2002), it is an ideal candidate for therapy. When mice with a mutated Sod1 gene are given intraperitoneal injections of TGF- $\beta 2$, they show rapid improvement in motor functions, but this improvement lasts for only a few weeks (Day et al. 2005). Thus, despite substantial evidence suggesting that TGF- $\beta$ signaling exerts an antiinflammatory and protective effect on the damaged nervous system, no convincing application has been shown.

\section{CONCLUSION}

The role of TGF- $\beta$ family members has been well characterized in the early stages of neural development in several organisms including mice. Spatiotemporal signals mediate effects of TGF- $\beta$ family members, allowing them to exert a wide range of functions from early stages of neurulation to later stages of development involving processes such as cellular specification, synaptogenesis, and axon guidance. The mechanisms involved later in development are less clear because of the need for multiple TGF- $\beta$ family gene mutations to overcome their redundant functions. Overall, we conclude that members of the TGF- $\beta$ family have important roles in virtually every stage of neural development. Continued study in the injured and diseased nervous system will have important clinical implications and could identify novel therapeutic targets.

\section{REFERENCES}

Abutbul S, Shapiro J, Szaingurten-Solodkin I, Levy N, Carmy Y, Baron R, Jung S, Monsonego A. 2012. TGF- $\beta$ signaling through SMAD2/3 induces the quiescent microglial phenotype within the CNS environment. Glia 60: 1160-1171.

Albert S, Müller F, Fischer N, Biellmann D, Neumann C, Blader P, Strähle U. 2003. Cyclops-independent floor plate differentiation in zebrafish embryos. Dev Dyn 226: 59-66.

Alder J, Lee KJ, Jessell TM, Hatten ME. 1999. Generation of cerebellar granule neurons in vivo by transplantation of 
BMP-treated neural progenitor cells. Nat Neurosci 2: 535-540.

Anderson RM, Lawrence AR, Stottmann RW, Bachiller D, Klingensmith J. 2002. Chordin and noggin promote organizing centers of forebrain development in the mouse. Development 129: 4975-4987.

Andersson E, Tryggvason U, Deng Q, Friling S, Alekseenko Z, Robert B, Perlmann T, Ericson J. 2006. Identification of intrinsic determinants of midbrain dopamine neurons. Cell 124: 393-405.

Andreasson K, Worley PF. 1995. Induction of $\beta$-A activin expression by synaptic activity and during neocortical development. Neuroscience 69: 781-796.

Angley C, Kumar M, Dinsio KJ, Hall AK, Siegel RE. 2003. Signaling by bone morphogenetic proteins and Smadl modulates the postnatal differentiation of cerebellar cells. J Neurosci 23: 260-268.

Apostolides C, Sanford E, Hong M, Mendez I. 1998. Glial cell line-derived neurotrophic factor improves intrastriatal graft survival of stored dopaminergic cells. Neuroscience 83: 363-372.

Arkell R, Beddington RS. 1997. BMP-7 influences pattern and growth of the developing hindbrain of mouse embryos. Development 124: 1-12.

Augsburger A, Schuchardt A, Hoskins S, Dodd J, Butler S. 1999. BMPs as mediators of roof plate repulsion of commissural neurons. Neuron 24: 127-141.

Bach A, Lallemand Y, Nicola MA, Ramos C, Mathis L, Maufras M, Robert B. 2003. Msxl is required for dorsal diencephalon patterning. Development 130: 4025-4036.

Bachiller D, Klingensmith J, Kemp C, Belo JA, Anderson RM, May SR, McMahon JA, McMahon AP, Harland RM, Rossant J, et al. 2000. The organizer factors Chordin and Noggin are required for mouse forebrain development. Nature 403: 658-661.

Baker JC, Beddington RS, Harland RM. 1999. Wnt signaling in Xenopus embryos inhibits bmp4 expression and activates neural development. Genes Dev 13: 3149-3159.

Barneda-Zahonero B, Miñano-Molina A, Badiola N, Fadó R, Xifró X, Saura CA, Rodríguez-Alvarez J. 2009. Bone morphogenetic protein- 6 promotes cerebellar granule neurons survival by activation of the MEK/ERK/CREB pathway. Mol Biol Cell 20: 5051-5063.

Basler K, Edlund T, Jessell TM, Yamada T. 1993. Control of cell pattern in the neural tube: Regulation of cell differentiation by dorsalin-1, a novel TGF $\beta$ family member. Cell 73: 687-702.

Beck HN, Drahushuk K, Jacoby DB, Higgins D, Lein PJ. 2001. Bone morphogenetic protein-5 (BMP-5) promotes dendritic growth in cultured sympathetic neurons. $B M C$ Neurosci 2: 12.

Bertolotto A, Capobianco M, Malucchi S, Manzardo E, Audano L, Bergui M, Bradac GB, Mutani R. 1999. Transforming growth factor $\beta 1$ (TGF $\beta 1$ ) mRNA level correlates with magnetic resonance imaging disease activity in multiple sclerosis patients. Neurosci Lett 263: 21-24.

Bertram L, Lill CM, Tanzi RE. 2010. The genetics of Alzheimer disease: Back to the future. Neuron 68: 270-281.

Bhalala OG, Pan L, Sahni V, McGuire TL, Gruner K, Tourtellotte WG, Kessler JA. 2012. microRNA-21 regulates astrocytic response following spinal cord injury. J Neurosci 32: 17935-17947.

Bissonnette CJ, Lyass L, Bhattacharyya BJ, Belmadani A, Miller RJ, Kessler JA. 2011. The controlled generation of functional basal forebrain cholinergic neurons from human embryonic stem cells. Stem Cells 29: 802-811.

Bonaguidi MA, McGuire T, Hu M, Kan L, Samanta J, Kessler JA. 2005. LIF and BMP signaling generate separate and discrete types of GFAP-expressing cells. Development 132: 5503-5514.

Bonaguidi MA, Peng CY, McGuire T, Falciglia G, Gobeske KT, Czeisler C, Kessler JA. 2008. Noggin expands neural stem cells in the adult hippocampus. J Neurosci 28: 91949204.

Bond AM, Peng CY, Meyers EA, McGuire T, Ewaleifoh O, Kessler JA. 2014. BMP signaling regulates the tempo of adult hippocampal progenitor maturation at multiple stages of the lineage. Stem Cells 32: 2201-2214.

Brionne TC, Tesseur I, Masliah E, Wyss-Coray T. 2003. Loss of TGF- $\beta 1$ leads to increased neuronal cell death and microgliosis in mouse brain. Neuron 40: 1133-1145.

Burke RE. 2003. Postnatal developmental programmed cell death in dopamine neurons. Ann NY Acad Sci 991: 6979.

Burton T, Liang B, Dibrov A, Amara F. 2002. Transcriptional activation and increase in expression of Alzheimer's $\beta$ amyloid precursor protein gene is mediated by TGF- $\beta$ in normal human astrocytes. Biochem Biophys Res Commun 295: 702-712.

Buss A, Pech K, Kakulas BA, Martin D, Schoenen J, Noth J, Brook GA. 2008. TGF- $\beta 1$ and TGF- $\beta 2$ expression after traumatic human spinal cord injury. Spinal Cord 46: 364-371.

Butler SJ, Dodd J. 2003. A role for BMP heterodimers in roof plate-mediated repulsion of commissural axons. Neuron 38: $389-401$.

Butovsky O, Jedrychowski MP, Moore CS, Cialic R, Lanser AJ, Gabriely G, Koeglsperger T, Dake B, Wu PM, Doykan $\mathrm{CE}$, et al. 2014. Identification of a unique TGF- $\beta$-dependent molecular and functional signature in microglia. Nature Neurosci 17: 131-143.

Calof AL, Bonnin A, Crocker C, Kawauchi S, Murray RC, Shou J, Wu HH. 2002. Progenitor cells of the olfactory receptor neuron lineage. Microsc Res Tech 58: 176-188.

Camus A, Perea-Gomez A, Moreau A, Collignon J. 2006. Absence of Nodal signaling promotes precocious neural differentiation in the mouse embryo. Dev Biol 295: 743755.

Caronia G, Wilcoxon J, Feldman P, Grove EA. 2010. Bone morphogenetic protein signaling in the developing telencephalon controls formation of the hippocampal dentate gyrus and modifies fear-related behavior. J Neurosc 30: 6291-6301.

Chalazonitis A, D'Autréaux F, Guha U, Pham TD, Faure C, Chen JJ, Roman D, Kan L, Rothman TP, Kessler JA, et al. 2004. Bone morphogenetic protein-2 and -4 limit the number of enteric neurons but promote development of a TrkC-expressing neurotrophin-3-dependent subset. J Neurosci 24: 4266-4282.

Chao CC, Hu S, Sheng WS, Peterson PK. 1995a. Tumor necrosis factor- $\alpha$ production by human fetal microglial 
cells: Regulation by other cytokines. Dev Neurosci 17: $97-$ 105.

Chao CC, Hu S, Sheng WS, Tsang M, Peterson PK. 1995b. Tumor necrosis factor- $\alpha$ mediates the release of bioactive transforming growth factor- $\beta$ in murine microglial cell cultures. Clin Immunol Immunopathol 77: 358-365.

Chapman SC, Schubert FR, Schoenwolf GC, Lumsden A. 2002. Analysis of spatial and temporal gene expression patterns in blastula and gastrula stage chick embryos. Dev Biol 245: 187-199.

Chen Y, Schier AF. 2001. The zebrafish Nodal signal Squint functions as a morphogen. Nature 411: 607-610.

Cheng X, Hsu CM, Currle DS, Hu JS, Barkovich AJ, Monuki ES. 2006. Central roles of the roof plate in telencephalic development and holoprosencephaly. J Neurosci 26: 7640-7649.

Chesnutt C, Burrus LW, Brown AM, Niswander L. 2004. Coordinate regulation of neural tube patterning and proliferation by TGF $\beta$ and WNT activity. Dev Biol 274: $334-$ 347.

Chiang C, Litingtung Y, Lee E, Young KE, Corden JL, Westphal H, Beachy PA. 1996. Cyclopia and defective axial patterning in mice lacking Sonic hedgehog gene function. Nature 383: 407-413.

Chin J, Angers A, Cleary LJ, Eskin A, Byrne JH. 1999. TGF$\beta 1$ in Aplysia: Role in long-term changes in the excitability of sensory neurons and distribution of T $\beta R$-II-like immunoreactivity. Learn Mem 6: 317-330.

Chizhikov VV, Millen KJ. 2004a. Control of roof plate formation by Lmxla in the developing spinal cord. Development 131: 2693-2705.

Chizhikov VV, Millen KJ. 2004b. Mechanisms of roof plate formation in the vertebrate CNS. Nat Rev Neurosci 5: $808-812$.

Chizhikov VV, Millen KJ. 2005. Roof plate-dependent patterning of the vertebrate dorsal central nervous system. Dev Biol 277: 287-295.

Chizhikov VV, Lindgren AG, Mishima Y, Roberts RW, Aldinger KA, Miesegaes GR, Currle DS, Monuki ES, Millen KJ. 2010. Lmxla regulates fates and location of cells originating from the cerebellar rhombic lip and telencephalic cortical hem. Proc Natl Acad Sci 107: 10725-10730.

Choi WY, Giraldez AJ, Schier AF. 2007. Target protectors reveal dampening and balancing of Nodal agonist and antagonist by miR-430. Science 318: 271-274.

Chou J, Luo Y, Kuo CC, Powers K, Shen H, Harvey BK, Hoffer BJ, Wang Y. 2008. Bone morphogenetic protein7 reduces toxicity induced by high doses of methamphetamine in rodents. Neuroscience 151: 92-103.

Colak D, Mori T, Brill MS, Pfeifer A, Falk S, Deng C, Monteiro R, Mummery C, Sommer L, Gotz M. 2008. Adult neurogenesis requires Smad4-mediated bone morphogenic protein signaling in stem cells. $J$ Neurosci 28: $434-446$.

Constam DB, Schmid P, Aguzzi A, Schachner M, Fontana A. 1994. Transient production of TGF- $\beta 2$ by postnatal cerebellar neurons and its effect on neuroblast proliferation. Eur J Neurosci 6: 766-778.

Costello DJ, O'Keeffe GW, Hurley FM, Sullivan AM. 2012. Transplantation of novel human GDF5-expressing CHO cells is neuroprotective in models of Parkinson's disease. $J$ Cell Mol Med 16: 2451-2460.

da Cunha A, Jefferson JA, Jackson RW, Vitkovic L. 1993. Glial cell-specific mechanisms of TGF- $\beta 1$ induction by IL-1 in cerebral cortex. J Neuroimmunol 42: 71-85.

Dale K, Sattar N, Heemskerk J, Clarke JD, Placzek M, Dodd J. 1999. Differential patterning of ventral midline cells by axial mesoderm is regulated by BMP7 and chordin. Development 126: 397-408.

Darabid H, Perez-Gonzalez AP, Robitaille R. 2014. Neuromuscular synaptogenesis: Coordinating partners with multiple functions. Nat Rev Neurosci 15: 703-718.

Day WA, Koishi K, Nukuda H, McLennan IS. 2005. Transforming growth factor- $\beta 2$ causes an acute improvement in the motor performance of transgenic ALS mice. Neurobiol Dis 19: 323-330.

Delaune E, Lemaire P, Kodjabachian L. 2005. Neural induction in Xenopus requires early FGF signalling in addition to BMP inhibition. Development 132: 299-310.

Dickinson ME, Selleck MA, McMahon AP, Bronner-Fraser M. 1995. Dorsalization of the neural tube by the nonneural ectoderm. Development 121: 2099-2106.

Dorey K, Amaya E. 2010. FGF signalling: Diverse roles during early vertebrate embryogenesis. Development 137: 3731-3742.

Dougan ST, Warga RM, Kane DA, Schier AF, Talbot WS. 2003. The role of the zebrafish nodal-related genes squint and cyclops in patterning of mesendoderm. Development 130: $1837-1851$.

Dünker N, Krieglstein K. 2003. Reduced programmed cell death in the retina and defects in lens and cornea of Tgf $\beta 2^{-/-} \operatorname{Tg} f 3^{-/-}$double-deficient mice. Cell Tissue Res 313: 1-10.

Dünker N, Schuster N, Krieglstein K. 2001. TGF- $\beta$ modulates programmed cell death in the retina of the developing chick embryo. Development 128: 1933-1942.

Dupont S, Zacchigna L, Cordenonsi M, Soligo S, Adorno M, Rugge M, Piccolo S. 2005. Germ-layer specification and control of cell growth by Ectodermin, a Smad4 ubiquitin ligase. Cell 121: 87-99.

Dutta DJ, Zameer A, Mariani JN, Zhang J, Asp L, Huynh J, Mahase S, Laitman BM, Argaw AT, Mitiku N, et al. 2014. Combinatorial actions of Tgf $\beta$ and Activin ligands promote oligodendrocyte development and CNS myelination. Development 141: 2414-2428.

Enzmann GU, Benton RL, Woock JP, Howard RM, Tsoulfas P, Whittemore SR. 2005. Consequences of noggin expression by neural stem, glial, and neuronal precursor cells engrafted into the injured spinal cord. Exp Neurol 195: 293-304.

Fainsod A, Deißler K, Yelin R, Marom K, Epstein M, Pillemer G, Steinbeisser H, Blum M. 1997. The dorsalizing and neural inducing gene follistatin is an antagonist of BMP-4. Mech Dev 63: 39-50.

Farkas LM, Dünker N, Roussa E, Unsicker K, Krieglstein K. 2003. Transforming growth factor- $\beta$ s are essential for the development of midbrain dopaminergic neurons in vitro and in vivo. J Neurosci 23: 5178-5186.

Fee DB, Sewell DL, Andresen K, Jacques TJ, Piaskowski S, Barger BA, Hart MN, Fabry Z. 2004. Traumatic brain 
injury increases TGF $\beta$ RII expression on endothelial cells. Brain Res 1012: 52-59.

Feldman B, Gates MA, Egan ES, Dougan ST, Rennebeck G, Sirotkin HI, Schier AF, Talbot WS. 1998. Zebrafish organizer development and germ-layer formation require nodal-related signals. Nature 395: 181-185.

Fernandes M, Gutin G, Alcorn H, McConnell SK, Hébert JM. 2007. Mutations in the BMP pathway in mice support the existence of two molecular classes of holoprosencephaly. Development 134: 3789-3794.

Fernandes M, Antoine M, Hébert JM. 2012. SMAD4 is essential for generating subtypes of neurons during cerebellar development. Dev Biol 365: 82-90.

Fuentealba LC, Eivers E, Ikeda A, Hurtado C, Kuroda H, Pera EM, De Robertis EM. 2007. Integrating patterning signals: Wnt/GSK3 regulates the duration of the BMP/ Smad1 signal. Cell 131: 980-993.

Fukuda S, Abematsu M, Mori H, Yanagisawa M, Kagawa T Nakashima K, Yoshimura A, Taga T. 2007. Potentiation of astrogliogenesis by STAT3-mediated activation of bone morphogenetic protein-Smad signaling in neural stem cells. Mol Cell Biol 27: 4931-4937.

Fukushima T, Liu RY, Byrne JH. 2007. Transforming growth factor- $\beta 2$ modulates synaptic efficacy and plasticity and induces phosphorylation of CREB in hippocampal neurons. Hippocampus 17: 5-9.

Fürthauer M, Thisse C, Thisse B. 1997. A role for FGF-8 in the dorsoventral patterning of the zebrafish gastrula. Development 124: 4253-4264.

Furuta Y, Piston DW, Hogan BL. 1997. Bone morphogenetic proteins (BMPs) as regulators of dorsal forebrain development. Development 124: 2203-2212.

Gestri G, Carl M, Appolloni I, Wilson SW, Barsacchi G, Andreazzoli M. 2005. Six3 functions in anterior neural plate specification by promoting cell proliferation and inhibiting Bmp4 expression. Development 132: 24012413.

Gokoffski KK, Wu HH, Beites CL, Kim J, Kim EJ, Matzuk MM, Johnson JE, Lander AD, Calof AL. 2011. Activin and GDF11 collaborate in feedback control of neuroepithelial stem cell proliferation and fate. Development 138: 4131-4142.

Gomes ME, Sikavitsas VI, Behravesh E, Reis RL, Mikos AG. 2003a. Effect of flow perfusion on the osteogenic differentiation of bone marrow stromal cells cultured on starch-based three-dimensional scaffolds. J Biomed Mater Res A 67: 87-95.

Gomes WA, Mehler MF, Kessler JA. 2003b. Transgenic overexpression of BMP4 increases astroglial and decreases oligodendroglial lineage commitment. Dev Biol 255: 164-177.

Gonzalez EM, Fekany-Lee K, Carmany-Rampey A, Erter C, Topczewski J, Wright CV, Solnica-Krezel L. 2000. Head and trunk in zebrafish arise via coinhibition of BMP signaling by bozozok and chordino. Genes Dev 14: 3087-3092.

Graham A, Francis-West P, Brickell P, Lumsden A. 1994. The signalling molecule BMP4 mediates apoptosis in the rhombencephalic neural crest. Nature 372: 684-686.

Grinspan JB, Edell E, Carpio DF, Beesley JS, Lavy L, Pleasure D, Golden JA. 2000. Stage-specific effects of bone mor- phogenetic proteins on the oligodendrocyte lineage. $J$ Neurobiol 43: 1-17.

Gross RE, Mehler MF, Mabie PC, Zang Z, Santschi L, Kessler JA. 1996. Bone morphogenetic proteins promote astroglial lineage commitment by mammalian subventricular zone progenitor cells. Neuron 17: 595-606.

Grove EA, Tole S, Limon J, Yip L, Ragsdale CW. 1998. The hem of the embryonic cerebral cortex is defined by the expression of multiple Wnt genes and is compromised in Gli3-deficient mice. Development 125: 2315-2325.

Gulacsi A, Lillien L. 2003. Sonic hedgehog and bone morphogenetic protein regulate interneuron development from dorsal telencephalic progenitors in vitro. J Neurosci 23: 9862-9872.

Guo X, Rueger D, Higgins D. 1998. Osteogenic protein-1 and related bone morphogenetic proteins regulate dendritic growth and the expression of microtubule-associated protein-2 in rat sympathetic neurons. Neurosci Lett 245: 131-134.

Harvey BK, Mark A, Chou J, Chen GJ, Hoffer BJ, Wang Y. 2004. Neurotrophic effects of bone morphogenetic protein-7 in a rat model of Parkinson's disease. Brain Res 1022: $88-95$.

Hatta K, Kimmel CB, Ho RK, Walker C. 1991. The cyclops mutation blocks specification of the floor plate of the zebrafish central nervous system. Nature 350: 339-341.

Hattori A, Katayama M, Iwasaki S, Ishii K, Tsujimoto M, Kohno M. 1999. Bone morphogenetic protein-2 promotes survival and differentiation of striatal GABAergic neurons in the absence of glial cell proliferation. J Neurochem 72: 2264-2271.

Hawley SH, Wunnenberg-Stapleton K, Hashimoto C, Laurent MN, Watabe T, Blumberg BW, Cho KW. 1995. Disruption of BMP signals in embryonic Xenopus ectoderm leads to direct neural induction. Genes Dev 9: 2923-2935.

Hazen VM, Phan KD, Hudiburgh S, Butler SJ. 2011. Inhibitory Smads differentially regulate cell fate specification and axon dynamics in the dorsal spinal cord. Dev Biol 356: $566-575$.

Hébert JM, Mishina Y, McConnell SK. 2002. BMP signaling is required locally to pattern the dorsal telencephalic midline. Neuron 35: 1029-1041.

Hébert JM, Hayhurst M, Marks ME, Kulessa H, Hogan BLM, McConnell SK. 2003. BMP ligands act redundantly to pattern the dorsal telencephalic midline. Genesis 35: 214-219.

Hemmati-Brivanlou A, Melton DA. 1992. A truncated activin receptor inhibits mesoderm induction and formation of axial structures in Xenopus embryos. Nature 359: 609614.

Hemmati-Brivanlou A, Melton DA. 1994. Inhibition of activin receptor signaling promotes neuralization in Xenopus. Cell 77: 273-281.

Hemmati-Brivanlou A, Kelly OG, Melton DA. 1994. Follistatin, an antagonist of activin, is expressed in the Spemann organizer and displays direct neuralizing activity. Cell 77: 283-295.

Henrich-Noack P, Prehn JH, Krieglstein J. 1996. TGF- $\beta 1$ protects hippocampal neurons against degeneration caused by transient global ischemia. Dose-response re- 
lationship and potential neuroprotective mechanisms. Stroke 27: 1609-1614.

Herrera-Molina R, von Bernhardi R. 2005. Transforming growth factor- $\beta 1$ produced by hippocampal cells modulates microglial reactivity in culture. Neurobiol Disease 19: 229-236.

Horbinski C, Stachowiak EK, Chandrasekaran V, Miuzukoshi E, Higgins D, Stachowiak MK. 2002. Bone morphogenetic protein-7 stimulates initial dendritic growth in sympathetic neurons through an intracellular fibroblast growth factor signaling pathway. J Neurochem 80: 54-63.

Huang WC, Yen FC, Shie FS, Pan CM, Shiao YJ, Yang CN, Huang FL, Sung YJ, Tsay HJ. 2010. TGF- $\beta 1$ blockade of microglial chemotaxis toward $A \beta$ aggregates involves SMAD signaling and down-regulation of CCL5. J Neuroinflamm 7: 28 .

Imayoshi I, Shimogori T, Ohtsuka T, Kageyama R. 2008. Hes genes and neurogenin regulate non-neural versus neural fate specification in the dorsal telencephalic midline. Development 135: 2531-2541.

Inui $\mathrm{M}$, Montagner M, Ben-Zvi D, Martello G, Soligo S, Manfrin A, Aragona M, Enzo E, Zacchigna L, Zanconato F, et al. 2012. Self-regulation of the head-inducing properties of the Spemann organizer. Proc Natl Acad Sci 109: 15354-15359.

Ishihara A, Saito H, Abe K. 1994. Transforming growth factor- $\beta 1$ and $-\beta 2$ promote neurite sprouting and elongation of cultured rat hippocampal neurons. Brain Res 639: $21-25$.

Ishikawa M, Nishijima N, Shiota J, Sakagami H, Tsuchida K, Mizukoshi M, Fukuchi M, Tsuda M, Tabuchi A. 2010. Involvement of the serum response factor coactivator megakaryoblastic leukemia (MKL) in the activin-regulated dendritic complexity of rat cortical neurons. J Bio Chem 285: 32734-32743.

Ishimura A, Maeda R, Takeda M, Kikkawa M, Daar IO, Maéno M. 2000. Involvement of BMP-4/msx-1 and FGF pathways in neural induction in the Xenopus embryo. Dev Growth Differ 42: 307-316.

Israsena N, Kessler JA. 2002. Ms $x 2$ and $p 21^{C I P 1 / W A F 1}$ mediate the proapoptotic effects of bone morphogenetic protein4 on ventricular zone progenitor cells. J Neurosci Res 69: 803-809.

Jordan J, Böttner M, Schluesener HJ, Unsicker K, Krieglstein K. 1997. Bone morphogenetic proteins: Neurotrophic roles for midbrain dopaminergic neurons and implications of astroglial cells. Eur J Neurosci 9: 1699-1709.

Kaartinen V, Voncken JW, Shuler C, Warburton D, Bu D, Heisterkamp N, Groffen J. 1995. Abnormal lung development and cleft palate in mice lacking TGF- $\beta 3$ indicates defects of epithelial-mesenchymal interaction. Nat $\mathrm{Ge}$ net 11: 415-421.

Kane CJ, Brown GJ, Phelan KD. 1996. Transforming growth factor- $\beta 2$ both stimulates and inhibits neurogenesis of rat cerebellar granule cells in culture. Brain Res Dev Brain Res 96: 46-51.

Kawauchi S, Beites CL, Crocker CE, Wu HH, Bonnin A, Murray R, Calof AL. 2004. Molecular signals regulating proliferation of stem and progenitor cells in mouse olfactory epithelium. Dev Neurosci 26: 166-180.
Khokha MK, Yeh J, Grammer TC, Harland RM. 2005. Depletion of three BMP antagonists from Spemann's organizer leads to a catastrophic loss of dorsal structures. Dev Cell 8: 401-411.

Kiecker C, Lumsden A. 2012. The role of organizers in patterning the nervous system. Ann Rev Neurosci 35: $347-$ 367.

Kretzschmar M, Doody J, Massagué J. 1997. Opposing BMP and EGF signalling pathways converge on the TGF- $\beta$ family mediator Smad1. Nature 389: 618-622.

Krieglstein K. 2013. TGF- $\beta$ in brain disorders. In TGF- $\beta$ in human disease (ed. Moustakas A, Miyazawa K), pp. 391 412. Springer, New York.

Krieglstein K, Unsicker K. 1994. Transforming growth factor- $\beta$ promotes survival of midbrain dopaminergic neurons and protects them against $N$-methyl-4-phenylpyridinium ion toxicity. Neuroscience 63: 1189-1196.

Krieglstein K, Unsicker K. 1996. Distinct modulatory actions of TGF- $\beta$ and LIF on neurotrophin-mediated survival of developing sensory neurons. Neurochem Res 21: 843-850.

Krieglstein K, Suter-Crazzolara C, Fischer WH, Unsicker K. $1995 \mathrm{a}$. TGF- $\beta$ superfamily members promote survival of midbrain dopaminergic neurons and protect them against MPP + toxicity. EMBO J 14: 736-742.

Krieglstein K, Suter-Crazzolara C, Hotten G, Pohl J, Unsicker K. 1995b. Trophic and protective effects of growth/differentiation factor 5 , a member of the transforming growth factor- $\beta$ superfamily, on midbrain dopaminergic neurons. J Neurosci Res 42: 724-732.

Krieglstein K, Henheik P, Farkas L, Jaszai J, Galter D, Krohn K, Unsicker K. 1998. Glial cell line-derived neurotrophic factor requires transforming growth factor- $\beta$ for exerting its full neurotrophic potential on peripheral and CNS neurons. J Neurosci 18: 9822-9834.

Krieglstein K, Richter S, Farkas L, Schuster N, Dünker N, Oppenheim RW, Unsicker K. 2000. Reduction of endogenous transforming growth factors $\beta$ prevents ontogenetic neuron death. Nat Neurosci 3: 1085-1090.

Krupinski J, Kumar P, Kumar S, Kaluza J. 1996. Increased expression of TGF- $\beta 1$ in brain tissue after ischemic stroke in humans. Stroke 27: 852-857.

Kuroda H, Wessely O, De Robertis EM. 2004. Neural induction in Xenopus: Requirement for ectodermal and endomesodermal signals via Chordin, Noggin, $\beta$-Catenin, and Cerberus. PLoS Biol 2: E92.

Lamb TM, Harland RM. 1995. Fibroblast growth factor is a direct neural inducer, which combined with noggin generates anterior-posterior neural pattern. Development 121: $3627-3636$.

Lander AD, Gokoffski KK, Wan FY, Nie Q, Calof AL. 2009. Cell lineages and the logic of proliferative control. PLoS Biol 7: e15.

Larraín J, Oelgeschläger M, Ketpura NI, Reversade B, Zakin L, De Robertis EM. 2001. Proteolytic cleavage of Chordin as a switch for the dual activities of twisted gastrulation in BMP signaling. Development 128: 4439-4447.

Lee KJ, Mendelsohn M, Jessell TM. 1998. Neuronal patterning by BMPs: A requirement for GDF7 in the generation of a discrete class of commissural interneurons in the mouse spinal cord. Genes Dev 12: 3394-3407. 
E.A. Meyers and J.A. Kessler

Lee KJ, Dietrich P, Jessell TM. 2000. Genetic ablation reveals that the roof plate is essential for dorsal interneuron specification. Nature 403: 734-740.

Lee JY, Koh HC, Chang MY, Park CH, Lee YS, Lee SH. 2003. Erythropoietin and bone morphogenetic protein $7 \mathrm{me}$ diate ascorbate-induced dopaminergic differentiation from embryonic mesencephalic precursors. Neuroreport 14: 1401-1404.

Lee HX, Ambrosio AL, Reversade B, De Robertis EM. 2006. Embryonic dorsal-ventral signaling: Secreted frizzled-related proteins as inhibitors of tolloid proteinases. Cell 124: $147-159$.

Lee-Hoeflich ST, Causing CG, Podkowa M, Zhao X, Wrana JL, Attisano L. 2004. Activation of LIMK1 by binding to the BMP receptor, BMPRII, regulates BMP-dependent dendritogenesis. EMBO J 23: 4792-4801.

Lehrmann E, Kiefer R, Finsen B, Diemer NH, Zimmer J, Hartung HP. 1995. Cytokines in cerebral ischemia: Expression of transforming growth factor $\beta 1$ (TGF- $\beta 1$ ) mRNA in the postischemic adult rat hippocampus. Exp Neurol 131: 114-123.

Lein P, Johnson M, Guo X, Rueger D, Higgins D. 1995. Osteogenic protein-1 induces dendritic growth in rat sympathetic neurons. Neuron 15: 597-605.

Lein P, Guo X, Hedges AM, Rueger D, Johnson M, Higgins D. 1996. The effects of extracellular matrix and osteogenic protein-1 on the morphological differentiation of rat sympathetic neurons. Int J Dev Neurosci 14: 203-215.

Le Roux P, Behar S, Higgins D, Charette M. 1999. OP-1 enhances dendritic growth from cerebral cortical neurons in vitro. Exp Neurol 160: 151-163.

Leung T, Bischof J, Söll I, Niessing D, Zhang D, Ma J, Jäckle H, Driever W. 2003. bozozok directly represses bmp2b transcription and mediates the earliest dorsoventral asymmetry of bmp2b expression in zebrafish. Development 130: 3639-3649.

Li W, Cogswell CA, LoTurco JJ. 1998. Neuronal differentiation of precursors in the neocortical ventricular zone is triggered by BMP. J Neurosci 18: 8853-8862.

Liem KF Jr, Tremml G, Roelink H, Jessell TM. 1995. Dorsal differentiation of neural plate cells induced by BMP-mediated signals from epidermal ectoderm. Cell 82: 969979.

Liem KF Jr, Tremml G, Jessell TM. 1997. A role for the roof plate and its resident TGF $\beta$-related proteins in neuronal patterning in the dorsal spinal cord. Cell 91: 127-138.

Liem KF Jr, Jessell TM, Briscoe J. 2000. Regulation of the neural patterning activity of sonic hedgehog by secreted BMP inhibitors expressed by notochord and somites. Development 127: 4855-4866.

Lim DA, Tramontin AD, Trevejo JM, Herrera DG, GarcíaVerdugo JM, Alvarez-Buylla A. 2000. Noggin antagonizes BMP signaling to create a niche for adult neurogenesis. Neuron 28: 713-726.

Lim Y, Cho G, Minarcik J, Golden J. 2005. Altered BMP signaling disrupts chick diencephalic development. Mech Dev 122: 603-620.

Lindholm D, Castren E, Kiefer R, Zafra F, Thoenen H. 1992a. Transforming growth factor- $\beta 1$ in the rat brain: Increase after injury and inhibition of astrocyte proliferation. $J$ Cell Biol 117: 395-400.
Lindholm D, Castrén E, Kiefer R, Zafra F, Thoenen H. 1992b. Transforming growth factor- $\beta 1$ in the rat brain: Increase after injury and inhibition of astrocyte proliferation. $J$ Cell Biol 117: 395-400.

Link J, Söderström M, Olsson T, Höjeberg B, Ljungdahl Å, Link H. 1994. Increased transforming growth factor- $\beta$, interleukin-4, and interferon- $\gamma$ in multiple sclerosis. Ann Neurol 36: 379-386.

Linker C, Stern CD. 2004. Neural induction requires BMP inhibition only as a late step, and involves signals other than FGF and Wnt antagonists. Development 131: 56715681.

Liu QR, Hattar S, Endo S, MacPhee K, Zhang H, Cleary LJ, Byrne JH, Eskin A. 1997. A developmental gene (Tolloid/ BMP-1) is regulated in Aplysia neurons by treatments that induce long-term sensitization. J Neurosci 17: 755-764.

Liu Y, Helms AW, Johnson JE. 2004. Distinct activities of Msx1 and Msx3 in dorsal neural tube development. Development 131: 1017-1028.

Lodge PA, Sriram S. 1996. Regulation of microglial activation by TGF- $\beta$, IL-10, and CSF-1. J Leukocyte Biol 60: 502-508.

López-Coviella I, Berse B, Krauss R, Thies RS, Blusztajn JK. 2000. Induction and maintenance of the neuronal cholinergic phenotype in the central nervous system by BMP-9. Science 289: 313-316.

López-Coviella I, Follettie MT, Mellott TJ, Kovacheva VP, Slack BE, Diesl V, Berse B, Thies RS, Blusztajn JK. 2005. Bone morphogenetic protein 9 induces the transcriptome of basal forebrain cholinergic neurons. Proc Natl Acad Sci 102: 6984-6989.

Luckenbill-Edds L. 1997. Laminin and the mechanism of neuronal outgrowth. Brain Res Brain Res Rev 23: 1-27.

Lupo G, Harris WA, Lewis KE. 2006. Mechanisms of ventral patterning in the vertebrate nervous system. Nat Rev Neurosci 7: 103-114.

Ma Q, Kintner C, Anderson DJ. 1996. Identification of neurogenin, a vertebrate neuronal determination gene. Cell 87: $43-52$.

Mabie PC, Mehler MF, Kessler JA. 1999. Multiple roles of bone morphogenetic protein signaling in the regulation of cortical cell number and phenotype. J Neurosci 19: 7077-7088.

Machold RP, Kittell DJ, Fishell GJ. 2007. Antagonism between Notch and bone morphogenetic protein receptor signaling regulates neurogenesis in the cerebellar rhombic lip. Neural Dev 2: 5 .

Makwana M, Jones LL, Cuthill D, Heuer H, Bohatschek M, Hristova M, Friedrichsen S, Ormsby I, Bueringer D, Koppius A, et al. 2007. Endogenous transforming growth factor $\beta 1$ suppresses inflammation and promotes survival in adult CNS. J Neurosci 27: 11201-11213.

Martello G, Zacchigna L, Inui M, Montagner M, Adorno M, Mamidi A, Morsut L, Soligo S, Tran U, Dupont S, et al. 2007. MicroRNA control of Nodal signalling. Nature 449: $183-188$.

Martinou JC, Le Van Thai A, Valette A, Weber MJ. 1990. Transforming growth factor $\beta 1$ is a potent survival factor for rat embryo motoneurons in culture. Brain Res Dev Brain Res 52: 175-181. 
Matsuura I, Endo M, Hata K, Kubo T, Yamaguchi A, Saeki N, Yamashita T. 2007. BMP inhibits neurite growth by a mechanism dependent on LIM-kinase. Biochem Biophys Res Comm 360: 868-873.

Matsuura I, Taniguchi J, Hata K, Saeki N, Yamashita T. 2008. BMP inhibition enhances axonal growth and functional recovery after spinal cord injury. J Neurochem 105: 1471 1479.

McKinnon RD, Piras G, Ida JA Jr, Dubois-Dalcq M. 1993. A role for TGF- $\beta$ in oligodendrocyte differentiation. J Cell Biol 121: 1397-1407.

McLennan IS, Koishi K. 2002. The transforming growth factor- $\beta$ s: Multifaceted regulators of the development and maintenance of skeletal muscles, motoneurons and Schwann cells. Intern J Dev Biol 46: 559-567.

McMahon JA, Takada S, Zimmerman LB, Fan CM, Harland RM, McMahon AP. 1998. Noggin-mediated antagonism of BMP signaling is required for growth and patterning of the neural tube and somite. Genes Dev 12: 1438-1452.

McNeill H, Williams C, Guan J, Dragunow M, Lawlor P, Sirimanne E, Nikolics K, Gluckman P. 1994. Neuronal rescue with transforming growth factor- $\beta 1$ after hypoxic-ischaemic brain injury. Neuroreport 5: 901-904.

McTigue DM, Popovich PG, Morgan TE, Stokes BT. 2000. Localization of transforming growth factor- $\beta 1$ and receptor mRNA after experimental spinal cord injury. Exp Neurol 163: 220-230.

Mehler MF, Marmur R, Gross R, Mabie PC, Zang Z, Papavasiliou A, Kessler JA. 1995. Cytokines regulate the cellular phenotype of developing neural lineage species. Intern J Dev Neurosci 13: 213-240.

Mehler MF, Mabie PC, Zhang D, Kessler JA. 1997. Bone morphogenetic proteins in the nervous system. Trends Neurosci 20: 309-317.

Mehler MF, Mabie PC, Zhu G, Gokhan S, Kessler JA. 2000. Developmental changes in progenitor cell responsiveness to bone morphogenetic proteins differentially modulate progressive CNS lineage fate. Dev Neurosci 22: 74-85.

Mekki-Dauriac S, Agius E, Kan P, Cochard P. 2002. Bone morphogenetic proteins negatively control oligodendrocyte precursor specification in the chick spinal cord. Development 129: $5117-5130$.

Meno C, Gritsman K, Ohishi S, Ohfuji Y, Heckscher E, Mochida K, Shimono A, Kondoh H, Talbot WS, Robertson EJ, et al. 1999. Mouse Lefty2 and zebrafish antivin are feedback inhibitors of nodal signaling during vertebrate gastrulation. Mol Cell 4: 287-298.

Meyers EA, Gobeske KT, Bond AM, Jarrett JC, Peng CY, Kessler JA. 2016. Increased bone morphogenetic protein signaling contributes to age-related declines in neurogenesis and cognition. Neurobiol Aging 38: 164-175.

Miller MW. 2003. Expression of transforming growth factor$\beta$ in developing rat cerebral cortex: Effects of prenatal exposure to ethanol. J Comp Neurol 460: 410-424.

Millonig JH, Millen KJ, Hatten ME. 2000. The mouse Dreher gene Lmxla controls formation of the roof plate in the vertebrate CNS. Nature 403: 764-769.

Mira H, Andreu Z, Suh H, Chichung Lie D, Jessberger S, Consiglio A, Emeterio JS, Hortigüela R, Marqués-Torrejón MA, Nakashima K, et al. 2010. Signaling through BMPR-IA regulates quiescence and long-term activity of neural stem cells in the adult hippocampus. Cell Stem Cell 7: 78-89.

Monuki ES, Porter FD, Walsh CA. 2001. Patterning of the dorsal telencephalon and cerebral cortex by a roof plateLhx2 pathway. Neuron 32: 591-604.

Moon BS, Yoon JY, Kim MY, Lee SH, Choi T, Choi KY. 2009. Bone morphogenetic protein 4 stimulates neuronal differentiation of neuronal stem cells through the ERK pathway. Exp Mol Med 41: 116-125.

Moos M Jr, Wang S, Krinks M. 1995. Anti-dorsalizing morphogenetic protein is a novel TGF- $\beta$ homolog expressed in the Spemann organizer. Development 121: 4293-4301.

Mukhopadhyay A, McGuire T, Peng CY, Kessler JA. 2009. Differential effects of BMP signaling on parvalbumin and somatostatin interneuron differentiation. Development 136: $2633-2642$.

Müller F, Chang BE, Albert S, Fischer N, Tora L, Strähle U. 1999. Intronic enhancers control expression of zebrafish sonic hedgehog in floor plate and notochord. Development 126: 2103-2116.

Müller F, Albert S, Blader P, Fischer N, Hallonet M, Strahle U. 2000. Direct action of the nodal-related signal cyclops in induction of sonic hedgehog in the ventral midline of the CNS. Development 127: 3889-3897.

Murphy SJ, Doré JJE, Edens M, Coffey RJ, Barnard JA, Mitchell H, Wilkes M, Leof EB. 2004. Differential trafficking of transforming growth factor- $\beta$ receptors and ligand in polarized epithelial cells. Mol Biol Cell 15: 2853-2862.

Nagatsu T, Mogi M, Ichinose H, Togari A. 2000. Changes in cytokines and neurotrophins in Parkinson's disease. $J$ Neural Transm Suppl 60: 277-290.

Nakashima M, Toyono T, Akamine A, Joyner A. 1999. Expression of growth/differentiation factor 11, a new member of the BMP/TGF $\beta$ superfamily during mouse embryogenesis. Mech Dev 80: 185-189.

Niehrs C. 2001. Developmental biology. Solving a sticky problem. Nature 413: 787-788.

Nomura M, Li E. 1998. Smad2 role in mesoderm formation, left-right patterning and craniofacial development. $\mathrm{Na}$ ture 393: 786-790.

Norton WH, Mangoli M, Lele Z, Pogoda HM, Diamond B, Mercurio S, Russell C, Teraoka H, Stickney HL, Rauch GJ, et al. 2005. Monorail/Foxa2 regulates floorplate differentiation and specification of oligodendrocytes, serotonergic raphé neurones and cranial motoneurones. Development 132: 645-658.

Oelgeschläger M, Larraín J, Geissert D, De Robertis EM. 2000. The evolutionarily conserved BMP-binding protein Twisted gastrulation promotes BMP signalling. $\mathrm{Na}$ ture 405: 757-763.

Oelgeschläger M, Reversade B, Larraín J, Little S, Mullins MC, De Robertis EM. 2003. The pro-BMP activity of Twisted Gastrulation is independent of BMP binding. Development 130: 4047-4056.

Onichtchouk D, Chen YG, Dosch R, Gawantka V, Delius H, Massagué J, Niehrs C. 1999. Silencing of TGF- $\beta$ signalling by the pseudoreceptor BAMBI. Nature 401: $480-$ 485 .

O'Sullivan DB, Harrison PT, Sullivan AM. 2010. Effects of GDF5 overexpression on embryonic rat dopaminergic 
neurones in vitro and in vivo. J Neur Transm 117: 559572.

Ozdamar B, Bose R, Barrios-Rodiles M, Wang HR, Zhang Y, Wrana JL. 2005. Regulation of the polarity protein Par6 by TGF $\beta$ receptors controls epithelial cell plasticity. Science 307: 1603-1609.

Patten I, Placzek M. 2002. Opponent activities of Shh and BMP signaling during floor plate induction in vivo. Curr Biol 2: 47-52.

Patten I, Kulesa P, Shen MM, Fraser S, Placzek M. 2003. Distinct modes of floor plate induction in the chick embryo. Development 130: 4809-4821.

Paulus W, Baur I, Huettner C, Schmaußer B, Roggendorf W, Schlingensiepen KH, Brysch W. 1995. Effects of transforming growth factor- $\beta 1$ on collagen synthesis, integrin expression, adhesion and invasion of glioma cells. J Neuropathol Exp Neurol 54: 236-244.

Pera EM, Wessely O, Li SY, De Robertis EM. 2001. Neural and head induction by insulin-like growth factor signals. Dev Cell 1: 655-665.

Pera EM, Ikeda A, Eivers E, De Robertis EM. 2003. Integration of IGF, FGF, and anti-BMP signals via Smad1 phosphorylation in neural induction. Genes Dev 17: 30233028.

Perea-Gomez A, Vella FD, Shawlot W, Oulad-Abdelghani M, Chazaud C, Meno C, Pfister V, Chen L, Robertson E, Hamada H, et al. 2002. Nodal antagonists in the anterior visceral endoderm prevent the formation of multiple primitive streaks. Dev Cell 3: 745-756.

Peretto P, Cummings D, Modena C, Behrens M, Venkatraman G, Fasolo A, Margolis FL. 2002. BMP mRNA and protein expression in the developing mouse olfactory system. J Comp Neurol 451: 267-278.

Perron JC, Dodd J. 2011. Inductive specification and axonal orientation of spinal neurons mediated by divergent bone morphogenetic protein signaling pathways. Neural Dev 6: 36 .

Perron JC, Dodd J. 2012. Structural distinctions in BMPs underlie divergent signaling in spinal neurons. Neural Dev 7: 16.

Peterziel H, Unsicker K, Krieglstein K. 2002. TGF $\beta$ induces GDNF responsiveness in neurons by recruitment of GFR $\alpha 1$ to the plasma membrane. J Cell Biol 159: 157167.

Piccolo S, Sasai Y, Lu B, De Robertis EM. 1996. Dorsoventral patterning in Xenopus: Inhibition of ventral signals by direct binding of chordin to BMP-4. Cell 86: 589-598.

Piccolo S, Agius E, Leyns L, Bhattacharyya S, Grunz H, Bouwmeester T, De Robertis EM. 1999. The head inducer Cerberus is a multifunctional antagonist of Nodal, BMP and Wnt signals. Nature 397: 707-710.

Placzek M, Briscoe J. 2005. The floor plate: Multiple cells, multiple signals. Nat Rev Neurosci 6: 230-240.

Platten M, Wick W, Wild-Bode C, Aulwurm S, Dichgans J, Weller M. 2000. Transforming growth factors $\beta 1$ (TGF$\beta 1)$ and TGF- $\beta 2$ promote glioma cell migration via upregulation of $\alpha \mathrm{V} \beta 3$ integrin expression. Biochem Biophys Res Comm 268: 607-611.

Podkowa M, Zhao X, Chow CW, Coffey ET, Davis RJ, Attisano L. 2010. Microtubule stabilization by bone morphogenetic protein receptor-mediated scaffolding of c-Jun
$\mathrm{N}$-terminal kinase promotes dendrite formation. $\mathrm{Mol}$ Cell Biol 30: 2241-2250.

Poulsen KT, Armanini MP, Klein RD, Hynes MA, Phillips HS, Rosenthal A. 1994. TGF 32 and TGF 33 are potent survival factors for midbrain dopaminergic neurons. Neuron 13: 1245-1252.

Prehn JH, Krieglstein J. 1994. Opposing effects of transforming growth factor- $\beta 1$ on glutamate neurotoxicity. Neuroscience 60: 7-10.

Proetzel G, Pawlowski SA, Wiles MV, Yin M, Boivin GP Howles PN, Ding J, Ferguson MW, Doetschman T. 1995. Transforming growth factor- $\beta 3$ is required for secondary palate fusion. Nat Genet 11: 409-414.

Qin L, Wine-Lee L, Ahn KJ, Crenshaw EB 3rd. 2006. Genetic analyses demonstrate that bone morphogenetic protein signaling is required for embryonic cerebellar development. J Neurosci 26: 1896-1905.

Rahhal B, Heermann S, Ferdinand A, Rosenbusch J, Rickmann M, Krieglstein K. 2009. In vivo requirement of TGF- $\beta /$ GDNF cooperativity in mouse development: Focus on the neurotrophic hypothesis. Int J Dev Neurosci 27: 97-102.

Rajan P, Panchision DM, Newell LF, McKay RD. 2003. BMPs signal alternately through a SMAD or FRAP-STAT pathway to regulate fate choice in CNS stem cells. J Cell Biol 161: $911-921$.

Rastegar S, Albert S, Le Roux I, Fischer N, Blader P, Muller F, Strahle U. 2002. A floor plate enhancer of the zebrafish netrin1 gene requires Cyclops (Nodal) signalling and the winged helix transcription factor FoxA2. Dev Biol 252: $1-14$.

Rebagliati MR, Toyama R, Haffter P, Dawid IB. 1998. Cyclops encodes a nodal-related factor involved in midline signaling. Proc Natl Acad Sci 95: 9932-9937.

Reversade B, De Robertis EM. 2005. Regulation of ADMP and BMP2/4/7 at opposite embryonic poles generates a self-regulating morphogenetic field. Cell 123: 11471160.

Reversade B, Kuroda H, Lee H, Mays A, De Robertis EM. 2005. Depletion of Bmp2, Bmp4, Bmp7 and Spemann organizer signals induces massive brain formation in Xenopus embryos. Development 132: 3381-3392.

Ross SE, Greenberg ME, Stiles CD. 2003. Basic helix-loophelix factors in cortical development. Neuron 39: 13-25.

Roussa E, Krieglstein K. 2004. Induction and specification of midbrain dopaminergic cells: Focus on SHH, FGF8, and TGF- $\beta$. Cell Tissue Res 318: 23-33.

Roussa E, Farkas LM, Krieglstein K. 2004. TGF- $\beta$ promotes survival on mesencephalic dopaminergic neurons in cooperation with Shh and FGF-8. Neurobiol Disease 16: 300-310.

Roussa E, Wiehle M, Dünker N, Becker-Katins S, Oehlke O, Krieglstein K. 2006. Transforming growth factor $\beta$ is required for differentiation of mouse mesencephalic progenitors into dopaminergic neurons in vitro and in vivo: Ectopic induction in dorsal mesencephalon. Stem Cells 24: $2120-2129$.

Roussa E, Oehlke O, Rahhal B, Heermann S, Heidrich S, Wiehle M, Krieglstein K. 2008. Transforming growth factor $\beta$ cooperates with persephin for dopaminergic phenotype induction. Stem Cells 26: 1683-1694. 
TGF- $\beta$ and Neural Development

Roussa E, von Bohlen und Halbach O, Krieglstein K. 2009. TGF- $\beta$ in dopamine neuron development, maintenance and neuroprotection. Adv Exp Med Biol 651: 81-90.

Sabo JK, Cate HS. 2013. Signalling pathways that inhibit the capacity of precursor cells for myelin repair. Int J Mol Sci 14: 1031-1049.

Sabo JK, Aumann TD, Merlo D, Kilpatrick TJ, Cate HS. 2011. Remyelination is altered by bone morphogenic protein signaling in demyelinated lesions. J Neurosci 31: 4504-4510.

Sahni V, Mukhopadhyay A, Tysseling V, Hebert A, Birch D, McGuire TL, Stupp SI, Kessler JA. 2010. BMPR1a and BMPR $1 b$ signaling exert opposing effects on gliosis after spinal cord injury. J Neurosci 30: 1839-1855.

Samanta J, Kessler JA. 2004. Interactions between ID and OLIG proteins mediate the inhibitory effects of BMP4 on oligodendroglial differentiation. Development 131: 4131-4142.

Samanta J, Burke GM, McGuire T, Pisarek AJ, Mukhopadhyay A, Mishina Y, Kessler JA. 2007. BMPR1a signaling determines numbers of oligodendrocytes and calbindinexpressing interneurons in the cortex. J Neurosci 27: 7397-7407.

Sanford LP, Ormsby I, Gittenberger-de Groot AC, Sariola H, Friedman R, Boivin GP, Cardell EL, Doetschman T. 1997. TGF 32 knockout mice have multiple developmental defects that are non-overlapping with other TGF $\beta$ knockout phenotypes. Development 124: 2659-2670.

Sapkota G, Alarcón C, Spagnoli FM, Brivanlou AH, Massagué J. 2007. Balancing BMP Signaling through Integrated Inputs into the Smad1 Linker. Mol Cell 25: 441454.

Sasai Y, Lu B, Steinbeisser H, Geissert D, Gont LK, De Robertis EM. 1994. Xenopus chordin: A novel dorsalizing factor activated by organizer-specific homeobox genes. Cell 79: 779-790.

Sasai Y, Lu B, Steinbeisser H, De Robertis EM. 1995. Regulation of neural induction by the Chd and Bmp-4 antagonistic patterning signals in Xenopus. Nature 377: 757.

Schluesener HJ, Meyermann R. 1994. Expression of BMP-6, a TGF- $\beta$ related morphogenetic cytokine, in rat radial glial cells. Glia 12: 161-164.

Schober A, Peterziel H, von Bartheld CS, Simon H, Krieglstein K, Unsicker K. 2007. GDNF applied to the MPTPlesioned nigrostriatal system requires TGF- $\beta$ for its neuroprotective action. Neurobiol Dis 25: 378-391.

Scholl C, Weißmüller K, Holenya P, Shaked-Rabi M, Tucker KL, Wölfl S. 2012. Distinct and overlapping gene regulatory networks in BMP- and HDAC-controlled cell fate determination in the embryonic forebrain. BMC Genomics 13: 298.

Schuman EM. 1997. Synapse specificity and long-term information storage. Neuron 18: 339-342.

See JM, Grinspan JB. 2009. Sending mixed signals: Bone morphogenetic protein in myelination and demyelination. J Neuropathol Exp Neurol 68: 595-604.

See J, Mamontov P, Ahn K, Wine-Lee L, Crenshaw EB III, Grinspan JB. 2007. BMP signaling mutant mice exhibit glial cell maturation defects. Mol Cell Neurosci 35: 171182.
Setoguchi T, Nakashima K, Takizawa T, Yanagisawa $\mathrm{M}$, Ochiai W, Okabe M, Yone K, Komiya S, Taga T. 2004. Treatment of spinal cord injury by transplantation of fetal neural precursor cells engineered to express BMP inhibitor. Exp Neurol 189: 33-44.

Shoji-Kasai Y, Ageta H, Hasegawa Y, Tsuchida K, Sugino H, Inokuchi K. 2007. Activin increases the number of synaptic contacts and the length of dendritic spine necks by modulating spinal actin dynamics. J Cell Sci 120: $3830-$ 3837.

Shou J, Rim PC, Calof AL. 1999. BMPs inhibit neurogenesis by a mechanism involving degradation of a transcription factor. Nat Neurosci 2: 339-345.

Shou J, Murray RC, Rim PC, Calof AL. 2000. Opposing effects of bone morphogenetic proteins on neuron production and survival in the olfactory receptor neuron lineage. Development 127: 5403-5413.

Siegenthaler JA, Miller MW. 2004. Transforming growth factor $\beta 1$ modulates cell migration in rat cortex: Effects of ethanol. Cereb Cortex 14: 791-802.

Söderström M, Hillert J, Link J, Navikas V, Fredrikson S, Link H. 1995. Expression of IFN- $\gamma$, IL-4, and TGF- $\beta$ in multiple sclerosis in relation to HLA-Dw2 phenotype and stage of disease. Mult Scler 1: 173-180.

Solloway MJ, Robertson EJ. 1999. Early embryonic lethality in Bmp5;Bmp7 double mutant mice suggests functional redundancy within the 60A subgroup. Development 126: $1753-1768$.

Sometani A, Kataoka H, Nitta A, Fukumitsu H, Nomoto H, Furukawa S. 2001. Transforming growth factor- $\beta 1$ enhances expression of brain-derived neurotrophic factor and its receptor, TrkB, in neurons cultured from rat cerebral cortex. J Neurosci Res 66: 369-376.

Song J, Oh SP, Schrewe H, Nomura M, Lei H, Okano M, Gridley T, Li E. 1999. The type II activin receptors are essential for egg cylinder growth, gastrulation, and rostral head development in mice. Devel Biol 213: 157-169.

Spemann H, Mangold H. 1924. The induction of embryonic predispositions by implantation of organizers foreign to the species. Arch Mikrosk Anat En 100: 599-638.

Spoelgen R, Hammes A, Anzenberger U, Zechner D, Andersen OM, Jerchow B, Willnow TE. 2005. LRP2/megalin is required for patterning of the ventral telencephalon. Development 132: 405-414.

Sullivan AM, Pohl J, Blunt SB. 1998. Growth/differentiation factor 5 and glial cell line-derived neurotrophic factor enhance survival and function of dopaminergic grafts in a rat model of Parkinson's disease. Eur J Neurosci 10: 3681-3688.

Sun Y, Nadal-Vicens M, Misono S, Lin MZ, Zubiaga A, Hua X, Fan G, Greenberg ME. 2001. Neurogenin promotes neurogenesis and inhibits glial differentiation by independent mechanisms. Cell 104: 365-376.

Suzuki A, Kaneko E, Ueno N, Hemmati-Brivanlou A. 1997a. Regulation of epidermal induction by BMP2 and BMP7 signaling. Dev Biol 189: 112-122.

Suzuki A, Ueno N, Hemmati-Brivanlou A. 1997b. Хenopus msx1 mediates epidermal induction and neural inhibition by BMP4. Development 124: 3037-3044.

Suzumura A, Sawada M, Yamamoto $H$, Marunouchi T. 1993. Transforming growth factor- $\beta$ suppresses activa- 
tion and proliferation of microglia in vitro. J Immunol 151: $2150-2158$.

Takizawa T, Ochiai W, Nakashima K, Taga T. 2003. Enhanced gene activation by Notch and BMP signaling cross-talk. Nucl Acids Res 31: 5723-5731.

ten Dijke P, Yamashita H, Sampath TK, Reddi AH, Estevez M, Riddle DL, Ichijo H, Heldin CH, Miyazono K. 1994. Identification of type I receptors for osteogenic protein-1 and bone morphogenetic protein-4. J Biol Chem 269: 16985-16988.

Tesseur I, Zou K, Esposito L, Bard F, Berber E, Can JV, Lin AH, Crews L, Tremblay P, Mathews P, et al. 2006. Deficiency in neuronal TGF- $\beta$ signaling promotes neurodegeneration and Alzheimer's pathology. J Clin Invest 116: 3060-3069.

Tesseur I, Zhang H, Brecht W, Corn J, Gong JS, Yanagisawa K, Michikawa M, Weisgraber K, Huang Y, Wyss-Coray T. 2009. Bioactive TGF- $\beta$ can associate with lipoproteins and is enriched in those containing apolipoprotein E3. J Neurochem 110: 1254-1262.

Timmer JR, Wang C, Niswander L. 2002. BMP signaling patterns the dorsal and intermediate neural tube via regulation of homeobox and helix-loop-helix transcription factors. Development 129: 2459-2472.

Tomoda T, Shirasawa T, Yahagi YI, Ishii K, Takagi H, Furiya Y, Arai KI, Mori H, Muramatsu MA. 1996. Transforming growth factor- $\beta$ is a survival factor for neonate cortical neurons: Coincident expression of type I receptors in developing cerebral cortices. Dev Biol 179: 79-90.

Toru-Delbauffe D, Baghdassarian-Chalaye D, Gavaret JM, Courtin F, Pomerance M, Pierre M. 1990. Effects of transforming growth factor $\beta 1$ on astroglial cells in culture. $J$ Neurochem 54: 1056-1061.

Tríbulo C, Aybar MJ, Nguyen VH, Mullins MC, Mayor R. 2003. Regulation of Msx genes by a Bmp gradient is essential for neural crest specification. Development 130: 6441-6452.

Ueberham U, Ueberham E, Gruschka H, Arendt T. 2006 Altered subcellular location of phosphorylated Smads in Alzheimer's disease. Eur J Neurosci 24: 2327-2334.

Unsicker K, Flanders KC, Cissel DS, Lafyatis R, Sporn MB. 1991. Transforming growth factor $\beta$ isoforms in the adult rat central and peripheral nervous system. Neurosci 44: $613-625$.

Unsicker K, Meier C, Krieglstein K, Sartor BM, Flanders KC. 1996. Expression, localization, and function of transforming growth factor- $\beta$ s in embryonic chick spinal cord, hindbrain, and dorsal root ganglia. J Neurobiol 29: $262-276$.

van der Wal EA, Gomez-Pinilla F, Cotman CW. 1993. Transforming growth factor- $\beta 1$ is in plaques in Alzheimer and Down pathologies. Neuroreport 4: 69-72.

Venström KA, Reichardt LF. 1993. Extracellular matrix. 2: Role of extracellular matrix molecules and their receptors in the nervous system. FASEB J 7: 996-1003.

Vogel-Höpker A, Rohrer H. 2002. The specification of noradrenergic locus coeruleus (LC) neurones depends on bone morphogenetic proteins (BMPs). Development 129: 983-991.
Wagner DS, Mullins MC. 2002. Modulation of BMP activity in dorsal-ventral pattern formation by the chordin and ogon antagonists. Dev Biol 245: 109-123.

Wang H, Liu J, Zong Y, Xu Y, Deng W, Zhu H, Liu Y, Ma C, Huang L, Zhang L, et al. 2010. miR-106b aberrantly expressed in a double transgenic mouse model for Alzheimer's disease targets TGF- $\beta$ type II receptor. Brain Res 1357: 166-174.

Wen Z, Han L, Bamburg JR, Shim S, Ming GL, Zheng JQ. 2007. BMP gradients steer nerve growth cones by a balancing act of LIM kinase and Slingshot phosphatase on ADF/cofilin. J Cell Biol 178: 107-119.

Weng Q, Chen Y, Wang H, Xu X, Yang B, He Q, Shou W, Chen Y, Higashi Y, van den Berghe V, et al. 2012. Dualmode modulation of Smad signaling by Smad-interacting protein Sip1 is required for myelination in the central nervous system. Neuron 73: 713-728.

Wick W, Platten M, Weller M. 2001. Glioma cell invasion: Regulation of metalloproteinase activity by TGF- $\beta$. $J$ Neurooncol 53: 177-185.

Wiendl H, Neuhaus O, Kappos L, Hohlfeld R. 2000. Multiple sclerosis. Current review of failed and discontinued clinical trials of drug treatment. Der Nervenarzt 71: 597 610.

Wijgerde M, McMahon JA, Rule M, McMahon AP. 2002. A direct requirement for Hedgehog signaling for normal specification of all ventral progenitor domains in the presumptive mammalian spinal cord. Genes Dev 16: 2849-2864.

Wilson PA, Hemmati-Brivanlou A. 1995. Induction of epidermis and inhibition of neural fate by Bmp-4. Nature 376: $331-333$.

Wilson PA, Lagna G, Suzuki A, Hemmati-Brivanlou A. 1997. Concentration-dependent patterning of the Xenopus ectoderm by BMP4 and its signal transducer Smad1. Development 124: 3177-3184.

Wilson SI, Graziano E, Harland R, Jessell TM, Edlund T. 2000. An early requirement for FGF signalling in the acquisition of neural cell fate in the chick embryo. Curr Biol 10: 421-429.

Wine-Lee L, Ahn KJ, Richardson RD, Mishina Y, Lyons KM, Crenshaw EB III. 2004. Signaling through BMP type 1 receptors is required for development of interneuron cell types in the dorsal spinal cord. Development 131: 53935403.

Withers GS, Higgins D, Charette M, Banker G. 2000. Bone morphogenetic protein-7 enhances dendritic growth and receptivity to innervation in cultured hippocampal neurons. Eur J Neurosci 12: 106-116.

Wood TK, McDermott KW, Sullivan AM. 2005. Differential effects of growth/differentiation factor 5 and glial cell line-derived neurotrophic factor on dopaminergic neurons and astroglia in cultures of embryonic rat midbrain. J Neurosci Res 80: 759-766.

Wu MY, Hill CS. 2009. TGF- $\beta$ superfamily signaling in embryonic development and homeostasis. Dev Cell 16: 329343.

Wu HH, Ivkovic S, Murray RC, Jaramillo S, Lyons KM, Johnson JE, Calof AL. 2003. Autoregulation of neurogenesis by GDF11. Neuron 37: 197-207. 
TGF- $\beta$ and Neural Development

Wu M, Hernandez M, Shen S, Sabo JK, Kelkar D, Wang J, O'Leary R, Phillips GR, Cate HS, Casaccia P. 2012. Differential modulation of the oligodendrocyte transcriptome by sonic hedgehog and bone morphogenetic protein 4 via opposing effects on histone acetylation. $J$ Neurosci 32: 6651-6664.

Wyss-Coray T, Borrow P, Brooker MJ, Mucke L. 1997. Astroglial overproduction of TGF- $\beta 1$ enhances inflammatory central nervous system disease in transgenic mice. $J$ Neuroimmunol 77: 45-50.

Wyss-Coray T, Lin C, Yan F, Yu GQ, Rohde M, McConlogue L, Masliah E, Mucke L. 2001. TGF- $\beta 1$ promotes microglial amyloid- $\beta$ clearance and reduces plaque burden in transgenic mice. Nat Med 7: 612-618.

Xu RH, Kim J, Taira M, Zhan S, Sredni D, Kung HF. 1995. A dominant negative bone morphogenetic protein 4 receptor causes neuralization in Xenopus ectoderm. Biochem Biophys Res Comm 212: 212-219.

Yabe T, Shimizu T, Muraoka O, Bae YK, Hirata T, Nojima H, Kawakami A, Hirano T, Hibi M. 2003. Ogon/Secreted Frizzled functions as a negative feedback regulator of Bmp signaling. Development 130: 2705-2716.

Yamamoto M, Saijoh Y, Perea-Gomez A, Shawlot W, Behringer RR, Ang SL, Hamada H, Meno C. 2004. Nodal antagonists regulate formation of the anteroposterior axis of the mouse embryo. Nature 428: 387-392.

Yan X, Liu Z, Chen Y. 2009. Regulation of TGF- $\beta$ signaling by Smad7. Acta Biochim Biophys Sinica 41: 263-272.

Yi JJ, Barnes AP, Hand R, Polleux F, Ehlers MD. 2010. TGF- $\beta$ signaling specifies axons during brain development. Cell 142: $144-157$.

Yung SY, Gokhan S, Jurcsak J, Molero AE, Abrajano JJ, Mehler MF. 2002. Differential modulation of BMP signaling promotes the elaboration of cerebral cortical GABAergic neurons or oligodendrocytes from a common sonic hedgehog-responsive ventral forebrain progenitor species. Proc Natl Acad Sci 99: 16273-16278.

Zakin L, De Robertis EM. 2010. Extracellular regulation of BMP signaling. Curr Biol 20: R89-92.

Zhang F, Endo S, Cleary LJ, Eskin A, Byrne JH. 1997. Role of transforming growth factor- $\beta$ in long-term synaptic facilitation in Aplysia. Science 275: 1318-1320.

Zhang D, Mehler MF, Song Q, Kessler JA. 1998. Development of bone morphogenetic protein receptors in the nervous system and possible roles in regulating trkC expression. J Neurosci 18: 3314-3326.

Zhang J, Pho V, Bonasera SJ, Holtzman J, Tang AT, Hellmuth J, Tang S, Janak PH, Tecott LH, Huang EJ. 2007. Essential function of HIPK2 in TGF $\beta$-dependent survival of midbrain dopamine neurons. Nat Neurosci 10: 77-86.

Zhou YX, Zhao M, Li D, Shimazu K, Sakata K, Deng CX, Lu B. 2003. Cerebellar deficits and hyperactivity in mice lacking Smad4. J Biol Chem 278: 42313-42320.

Zhu G, Mehler MF, Mabie PC, Kessler JA. 1999a. Developmental changes in progenitor cell responsiveness to cytokines. J Neurosci Res 56: 131-145.

Zhu H, Kavsak P, Abdollah S, Wrana JL, Thomsen GH. 1999b. A SMAD ubiquitin ligase targets the BMP pathway and affects embryonic pattern formation. Nature 400: 687-693.

Zhu Y, Roth-Eichhorn S, Braun N, Culmsee C, Rami A, Krieglstein J. 2000. The expression of transforming growth factor- $\beta 1$ (TGF- $\beta 1$ ) in hippocampal neurons: A temporary upregulated protein level after transient forebrain ischemia in the rat. Brain Res 866: 286-298.

Zimmerman LB, De Jesús-Escobar JM, Harland RM. 1996. The Spemann organizer signal noggin binds and inactivates bone morphogenetic protein 4. Cell 86: 599-606. 


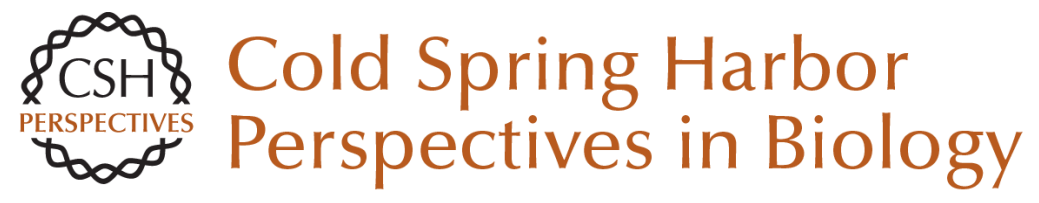

\section{TGF- $\beta$ Family Signaling in Neural and Neuronal Differentiation, Development, and Function}

Emily A. Meyers and John A. Kessler

Cold Spring Harb Perspect Biol 2017; doi: 10.1101/cshperspect.a022244 originally published online January 27, 2017

Subject Collection The Biology of the TGF-\&\#946; Family

TGF- $\beta$ Family Signaling in Early Vertebrate

Development

Joseph Zinski, Benjamin Tajer and Mary C. Mullins

Bone Morphogenetic Protein-Based Therapeutic

Approaches

Jonathan W. Lowery and Vicki Rosen

TGF- $\beta$ Family Signaling in Ductal Differentiation

and Branching Morphogenesis

Kaoru Kahata, Varun Maturi and Aristidis

Moustakas

TGF- $\beta$ Signaling in Control of Cardiovascular

Function

Marie-José Goumans and Peter ten Dijke

TGF- $\beta$ Family Signaling in Tumor Suppression and Cancer Progression

Joan Seoane and Roger R. Gomis

Targeting TGF- $\beta$ Signaling for Therapeutic Gain Rosemary J. Akhurst

Regulation of Hematopoiesis and Hematological Disease by TGF- $\beta$ Family Signaling Molecules Kazuhito Naka and Atsushi Hirao
TGF- $\beta$ Family Signaling in Mesenchymal

Differentiation

Ingo Grafe, Stefanie Alexander, Jonathan $R$.

Peterson, et al.

TGF- $\beta 1$ Signaling and Tissue Fibrosis

Kevin K. Kim, Dean Sheppard and Harold A.

Chapman

Bone Morphogenetic Proteins in Vascular

Homeostasis and Disease

Marie-José Goumans, An Zwijsen, Peter ten Dijke, et al.

TGF- $\beta$ Family Signaling in Epithelial

Differentiation and Epithelial-Mesenchymal

Transition

Kaoru Kahata, Mahsa Shahidi Dadras and Aristidis Moustakas

TGF- $\beta$ Family Signaling in Connective Tissue and

Skeletal Diseases

Elena Gallo MacFarlane, Julia Haupt, Harry C.

Dietz, et al.

The TGF- $\beta$ Family in the Reproductive Tract

Diana Monsivais, Martin M. Matzuk and Stephanie A. Pangas

TGF- $\beta$ Family Signaling in Drosophila Ambuj Upadhyay, Lindsay Moss-Taylor, Myung-Jun Kim, et al.

For additional articles in this collection, see http://cshperspectives.cshlp.org/cgi/collection/

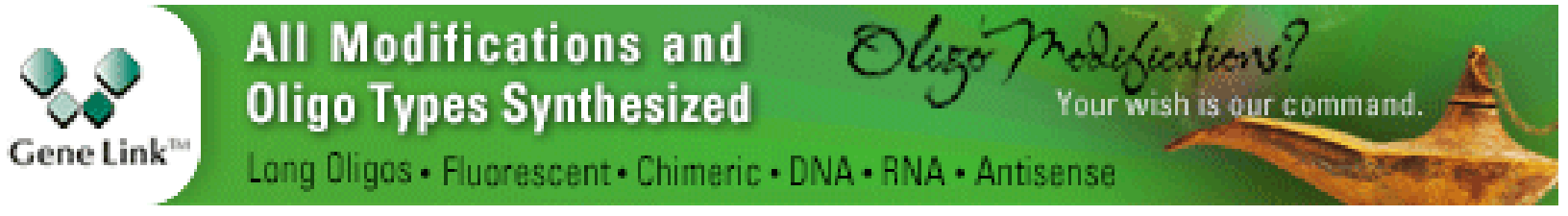

Copyright @ 2017 Cold Spring Harbor Laboratory Press; all rights reserved 
TGF- $\beta$ Family Signaling in Neural and Neuronal Differentiation, Development, and Function Emily A. Meyers and John A. Kessler
Signaling Cross Talk between TGF- $\beta /$ Smad and Other Signaling Pathways Kunxin LuO

For additional articles in this collection, see http://cshperspectives.cshlp.org/cgi/collection/

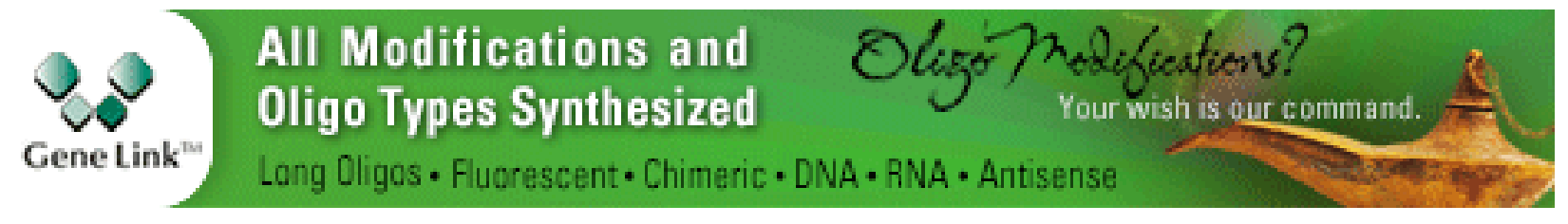

Copyright @ 2017 Cold Spring Harbor Laboratory Press; all rights reserved 